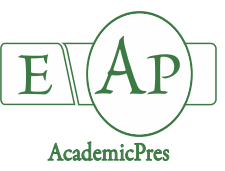

Shahrajabian MHet al. (2021)

NotulaeBotanicaeHortiAgrobotanici Cluj-Napoca

Volume 49, Issue 3, Article number 12183

DOI: $10.15835 /$ nbha 49312183

ReviewArticle

\title{
The importance of Rhizobium, Agrobacterium, Bradyrhizobium, Herbaspirillum, Sinorhizobium in sustainable agricultural production
}

\section{Mohamad H. SHAHRAJABIAN ${ }^{1 a}$, Wenli SUN ${ }^{16 *}$, Qi CHENG ${ }^{2}$}

\author{
${ }^{1}$ Chinese Academy of Agricultural Sciences, Biotechnology Research Institute, Beijing 100081, China \\ ${ }^{2}$ State Key Laboratory of North China Crop Improvement and Regulation, Hebei Agricultural University, College of Life Sciences, \\ Baoding, Hebei 071000, China; Global Alliance of HeBAU-CLS\&HeQiS for BioAl-Manufacturing, College of Life Sciences, Hebei \\ AgriculturalUniversity, Baoding,071000,China; hesamshahrajabian@gmail.com; sunwenli@caas.cn; chengqi@caas.cn; \\ sunwenli@caas.cn ("corresponding author) \\ ${ }^{a, b}$ These authors equally contributed to the work
}

\begin{abstract}
Rhizobia which are soil bacteria capable of symbiosis with legume plants in the root or stem nodules and perform nitrogen fixation. Rhizobial genera include Agrobacterium, Allorhizobium, Aminobacter, Azorhizobium, Bradyrhizobium, Devosia, Mesorhizobium, Methylobacterium, Microvirga, Ochrobacterum, Phyllobacterium, Rhizobium, Shinella and Ensifer (Sinorhizobium). Review of the literature was carried out using the keywords Rhizobium, Agrobacterium, Bradyrhizobium, Herbaspirillum and Sinorhizobium. Rhizobial nodulation symbioses steps are included flavonoid signaling, Nod factor induction, and Nod factor perception, root hair responses, rhizobial infection, cell division and formation of nitrogen-fixing nodule. Rhizobium improves sustainable production by boosting organic nitrogen content.
\end{abstract}

Keywords: nod; rhizobial genera; rhizobial nodulation; sustainable production

\section{Introduction}

The food shortage is expecting in coming year as the population of the world has increased very fast (Khoshkharam et al., 2010; Riaziat et al., 2012; Soleymani et al., 2016; Shahrajabian et al., 2020), while climate change and natural resource depletion has caused many problems in food security (Soleymani et al., 2011a,b; Yazdpour et al., 2012; Abdollahi et al., 2018; Shahrajabian et al., 2019a,b; Sun et al., 2019, 2020). Rhizobia which are soil bacteria capable of symbiosis with legume plants in root or stem nodules and perform nitrogen fixation for the host (De Meyer et al., 2015) are traditionally belong to the genera Azorhizobium, Sinorhizobium, Bradyrhizobium, Ensifer, Mesorhizobium and Rhizobium (Sawada et al., 2003; Nandasena et al., 2004). Rhizobia are Proteobacteria (Mousavi et al., 2014) and Rhizobial genera include Agrobacterium, Allorhizobium, Aminobacter, Azorhizobium, Bradyrhizobium, Devosia, Mesorhizobium, Methylobacterium, Microvirga, Ochrobacterum, Phyllobacterium, Rhizobium, Shinella and Ensifer (Sinorhizobium) (Lindstrom and Mousavi, 2010; Lindstrom et al., 2013). Root nodulation is interaction of compatible rhizobia which activates an array of genes which result in nodule development (Das et al., 2019). The bacteria reduce dinitrogen to ammonium inside the legume-root nodule in exchange for a carbon and energy source (Prell and

Received: 10 Dec 2020. Received in revised form: 30 Jul2021. Accepted: 03 Sep 2021. Published online: 10 Sep 2021.

From Volume 49, Issue 1, 2021, Notulae Botanicae Horti Agrobotanici Cluj-Napoca journal uses article numbers in place of the traditional method of continuous pagination through the volume. The journal will continue to appear quarterly, as before, with four annual numbers. 
Poole, 2006). The ability of adaptation of Rhizobia in diverse environment namely soil, rhizosphere and grown within legume roots may lead to nitrogen fixation, in a complicated process which contain a coordinated exchange of signal between the symbionts and plants (Ghosh and Maiti, 2016; Jack et al., 2019; Torabian et al., 2019). Nodulation also varied on the basis of the species and site (Rejili et al., 2012). Two distinct types of nodules are formed on legumes, namely determinate which are usually formed on common plants in tropical regions such as Glycine max, Lotus japonicus or Vicia faba, and indeterminate (Gibson et al., 2008; Haag et al., 2013). The most important examples of indeterminate-type nodules are Medicago, Trifolium, Pisum, and Vicia spp. (Janczarek et al., 2015; Bahroun et al., 2018). The most notable plant flavonoids are Flavones, Flavonols, Flavanones, Isoflavones, and Chalcones (Janczarek et al., 2015). There are almost 50 nodule-forming bacterial species within the genera (Wang et al., 2006; Hang et al., 2008). Nodule-forming bacteria is shown in Table 1. The most important characteristics of indeterminate and determinate nodules are indicated in Table 2. The list of some important Rhizobium species and their corresponding hosts are presented in Table 3 . The metabolic diversity of rhizobia on the basis of their large, complex genomes is shown in Table 4.

Table 1. Nodule-forming bacteria

\begin{tabular}{|l|c|}
\hline \multicolumn{1}{|c|}{ Genera } & Type \\
\hline & Agrobacterium, Allorhizobium, Azorhizobium, \\
The alpha-proteobacterial genera & Bradyrhizobium, Mesorhizobium, Rhizobium, \\
& Sinorhizobium, Devosia, Methylobacterium, \\
& Ochrobactrum, Phyllobacterium \\
\hline The beta-proteobacterial genera & Burkholderia, Cupriavidus \\
\hline
\end{tabular}

Table 2. The most important characteristics of indeterminate and determinate nodules

\begin{tabular}{|l|c|c|}
\hline \multicolumn{1}{|c|}{ Characteristic } & Determinate & Indeterminate \\
\hline Host plant & Bean, Soybean, Lotus & Alfalfa, Pea, Medicago truncatula \\
\hline Nodule shape & Spherical & Elongated \\
\hline Nodule growth & Cell expansion & Cell division. Persistent meristem \\
\hline Initial cell divisions & Outer cortex & Inner cortex \\
\hline Flavonoids including nod genes & Flavones, Flavonones & Isoflavones \\
\hline
\end{tabular}

Table 3. The list of some important Rhizobium species and their corresponding hosts

\begin{tabular}{|l|c|}
\hline \multicolumn{1}{|c|}{ Rhizobium species } & Host plants \\
\hline Bradyrhizobium japanicum & Glycine max (soybean) \\
\hline Rhizobium fredii & Glycine max (soybean) \\
\hline R.phaseoli & Phaseolus vulgaris (common bean) \\
\hline S. meliloti & Medicago sativa (alfalfa) \\
\hline & Melilotus sp. (sweet clovers) \\
\hline Rhizobium leguminosarum bv. trifolii & Trifolium sp. (clovers) \\
\hline R. leguminosarum & Pisum sativum (peas) \\
\hline & Vicia faba (broad bean) \\
\hline Rhizobium sp. or cowpea rhizobia group & Vigna unguiculata (cowpea) \\
\hline & Arachis hypogaea (peanut) \\
\hline & Vigna subterranean (Bambara groundnut) \\
\hline Azorhizobium caulinodans & Leucaena sp., Albizia sp., \\
\hline
\end{tabular}


Table 4. The metabolic diversity of rhizobia on the basis of their large, complex genomes

\begin{tabular}{|l|c|}
\hline \multicolumn{1}{|c|}{ Rhizobia } & Range \\
\hline Rhizobium etli & $6.5 \mathrm{Mb}$ \\
\hline Sinorhizobium meliloti & $6.7 \mathrm{Mb}$ (Giraud and Fleischman 2004) \\
\hline Mesorhizobium loti & $7.6 \mathrm{Mb}$ (Kaneko et al., 2000) \\
\hline Rhizobium leguminosarum & $7.8 \mathrm{Mb}$ \\
\hline Bradyrhizobium japonicum & $9.1 \mathrm{Mb}$ (Kaneko et al., 2002) \\
\hline
\end{tabular}

Rhizobial modulation symbioses consists of flavonoid signaling, Nod factor induction and perception, root hair responses which included calcium flux and spiking, gene expression), rhizoial infection, cell division and nitrogen-fixing nodule formation. The most important alphaproteobacteria are 1) Allorhizobium included, Aminobacter, Azorhizobium, Bradyrhizobium, Devosia, Mesorhizobium, Methylobacterium, Microvirga, Neorhizobium, Ochrobactrum, Phyloobacterium, Rhizobium, Shinella, Sinorhizobium (Ensifer), 2) Betaproteobacteris, consists of Cupriavidus, Paraburkholderia and Trinickia, and 3) Gamaproteobacteria. In this manuscript, we want to review Rhizobium, Agrobacterium, Bradyrhizobium, Herbaspirillum, and Sinorhizobium.

\section{Rhizobium}

The most important group of nitrogen fixing soil bacteria which can lead to mutualistic symbiotic association (root nodules) with leguminous plants are rhizobia (Gage, 2004: Werner, 2007; van Ham et al., 2016). Rhizobium improves sustainable production by boosting organic nitrogen content (Youseif et al., 2014; Vanlauwe et al., 2019; Karoneyet al., 2020). The gram-negative rod-shaped bacteria was first discovered by Frank (1889). Indole acetic acid (IAA) catabolising enzyme in nodule, root, and 1-aminocyclopropane-1carboxylic acid (ACC) deaminase activity have significant important in plant growth promotion and plantmicrobes interaction of symbiotic phenomenon (Ghosh et al., 2013). Notable parameters which have been related to successful establishment of the symbiotic interaction are chemotaxis of the bacteria towards the roots, root colonization and its hair deformation, infection thread formation, and rapid division or root cortex cells (Spaink et al., 1998, 1992; Dardanelli et al., 2008; Junier et al., 2014; van Zeijl et al., 2015; Wang et al., 2016). Rhizobia produce Nod factors during the early development of nodules upon perception of flavonoid molecules secreted by legume roots (Servin-Garciduenas et al., 2014; Shamseldin et al., 2014), and Nod factors structure depends on species, chemical substitutions added which may impact legume specificity (D'Haeze and Holsters, 2002; Feng et al., 2002; Geurts and Bisseling, 2002). More than 44-66 million tons of nitrogen biologically fixed per year which provide half of requirements in agriculture (Alberton et al., 2006; Acosta et al., 2011). Nitrogen fixation and legumes yields depends on the rhizobium strain, the genotype of the legume, bio-physical environment, and management practices (Giller et al., 2013; Tong et al., 2018; Wolde-meskel et al., 2018; Flores-Felix et al., 2019). The combination of Rhizobium and Arbuscular mycorrhiza are more effective than individual applications as the highest root colonization, root nodulation and the maximum yield of chickpea (Cicer arietinum L.) was related to combined application of these treatments (Erman et al., 2011). Ahmad et al. (2013) observed that Rhizobium and Pseudomonas strains can improve the growth, physiology, and quality of mung bean under salt-affected conditions. Shaping rhizobial species-level taxonomic biogeography maybe under the influence direct or indirect impacts of abiotic and biotic soil factors and legume hosts (Ide Franzini et al., 2010; Uyanoz and Karaca, 2011; Xiong et al., 2017; Gao et al., 2019). Cao et al. (2017) found soil factors shaped the rhizobial populations stronger compare to the geographic distance. Moreover, the native rhizobia differed by site (Yadav and Verma, 2014; Mwenda et al., 2018; Stefan et al., 2018). Rhizobium and cyanobacteria inoculants have positive feedback on plant growth and legumes yields (Babu et al., 2015). Inoculation of Rhizobium pisi and Pseudomonas monteilii is a promising biofertilization 
strategy for common bean production (Sanchez et al., 2014). Different rhizobiums and their usages are shown in Table 5.

Table 5. Different Rhizobium and their usages

\begin{tabular}{|c|c|c|}
\hline Rhizobium & Application and mechanism & Reference \\
\hline Rhizobium leguminosarum & $\begin{array}{c}\text { It can nodulate Lathyrus spp., Pisum sativum, } \\
\text { Melilotus indicus, Robinia pseudoacacia, } \\
\text { Securigera varia, Trifolium and Vicia plants }\end{array}$ & $\begin{array}{c}\text { Weir et al. (2004) } \\
\text { Alvarez-Martinez et al. (2009) Ramirez- } \\
\text { Bahena et al. (2009) } \\
\text { De Mayer et al. (2011) } \\
\text { Rogel et al. (2011) } \\
\text { Marek-Kozaczuk et al. (2013) }\end{array}$ \\
\hline $\begin{array}{l}\text { Chloralla vulgaris-Rhizobium sp. mixotrophic } \\
\text { co-cultivation }\end{array}$ & $\begin{array}{c}\text { It can be applied for wastewater reclamation in } \\
\text { continuous mode at multiple hydraulic } \\
\text { retention times (HRT) of 3-7 days }\end{array}$ & Ferro et al. (2019) \\
\hline Rhizobium sp. & Reduction of lipid accumulation in microalgae & Fei et al. (2019) \\
\hline Rhizobium species & Promote algal growth & $\begin{array}{c}\text { Gonzalez and Bashan (2000) } \\
\text { Yao et al. (2019) }\end{array}$ \\
\hline Rhizobium laguerreae & $\begin{array}{l}\text { It is the main nitrogen fixing symbiont of lentil } \\
\text { (Lens culinaris) }\end{array}$ & $\begin{array}{l}\text { Moswad and Beck (1991) } \\
\text { Laguerre et al. }(1992) \\
\text { Tian et al. }(2010) \\
\text { Riahet al. }(2014) \\
\text { Taha et al. }(2018)\end{array}$ \\
\hline Rhizobium meliloti & $\begin{array}{l}\text { Alfalfa and Rhizobium symbiotic association } \\
\text { may stimulate the rhizosphere microflora is a } \\
\text { useful method for aged polycyclic aromatic } \\
\text { hydrocarbons (PAHs)-contaminated soils }\end{array}$ & $\begin{array}{c}\text { Mehmannavaz etal. (2002) } \\
\text { Chekoletal. (2004) } \\
\text { Radwan et al. }(2007) \\
\text { Teng et al. (2011) } \\
\text { Sanchez-Pardo and Zornoza (2014) Deepika } \\
\text { et al. (2016) } \\
\text { Cardoso et al. (2018) } \\
\text { Duan et al. (2019) } \\
\text { Ju et al. (2019) }\end{array}$ \\
\hline Rhizobium rhizogenes & $\begin{array}{l}\text { Its T-DNA is involved in fasciation of } \\
\text { Nicotiana leaves. It also contains a highly } \\
\text { mosaic genetic organization in tumorigenic } \\
\text { strains. The pathogenic strains of Rhizobium } \\
\text { could be considered as model to analyse } \\
\text { bacterial evolution }\end{array}$ & Velazquez et al. (2010) \\
\hline Rhizobium & $\begin{array}{c}\text { There is one alcohol dehydrogenase encoding } \\
\text { gene in Rhizobium, and aldo-keto reductases } \\
\text { which decrease aldehydes to alcohols }\end{array}$ & $\begin{array}{l}\text { Sadowskyt and Bohloot (1986) } \\
\text { Willis and Walker (1998) } \\
\text { Pizzimentiet al. (2013) } \\
\text { Matos et al. (2019) }\end{array}$ \\
\hline $\begin{array}{l}\text { The molecular structure of rhizobium } \\
\text { exopolysaccharide (REPS) }\end{array}$ & $\begin{array}{c}\text { REPS polysaccharide possesses antitumor } \\
\text { activity }\end{array}$ & Zhao et al. (2010) \\
\hline Rhizobium massiliae & $\begin{array}{l}\text { Its water-soluble extracellular polysaccharide } \\
\text { (WSP) of } R \text {. massiliae CA-1 can be used as a } \\
\text { new immunomodulatory enhancing the early } \\
\text { innate immunity }\end{array}$ & Kim et al. (2017) \\
\hline Rhizobium radiobacter $C A S$ & $\begin{array}{l}\text { Its physic-functional properties make it an } \\
\text { important candidate for food processing and } \\
\text { also product development sector }\end{array}$ & Kavitake et al. (2019) \\
\hline Rhizobium & $\begin{array}{l}\text { Rhizobum strain contained ALK gene which } \\
\text { revealed strong Nonylphenol (NP) } \\
\text { degradation ability in liquid culture and } \\
\text { showed a potential bio-remediating NP- } \\
\text { contaminated sediment } \\
\end{array}$ & Wang et al. (2014) \\
\hline Rhizobium spp. & $\begin{array}{l}\text { Pre-treatment of chickpea seedlings with } \\
\text { Rhizobium spp. isolates activates genes } \\
\text { involved in the phenylpropanoid pathway by } \\
\text { promoting the accumulation of phenolic } \\
\text { compounds }\end{array}$ & Arfaoui et al. (2007) \\
\hline Rhizobium sp. MRP1 & $\begin{array}{l}\text { It can be used as bacterial inoculants to boost } \\
\text { pea production in fields which are polluted }\end{array}$ & Ahemad and Khan (2011) \\
\hline
\end{tabular}


Shahrajabian MHet al. (2021). Not Bot HortiAgrobo 49(3):12183

\begin{tabular}{|c|c|c|}
\hline & with fungicides & \\
\hline Rhizobium tropici & $\begin{array}{c}\text { Symbiosis of common bean's root and rhizobia } \\
\text { can decrease the negative effects made by the } \\
\text { allelopathic plant }\end{array}$ & Perez-Peralta et al. (2019) \\
\hline $\begin{array}{l}\text { Rhizobium bangladeshense } \\
\text { Rhizobium aegyptiacum }\end{array}$ & $\begin{array}{c}\text { Nodulation of these Rhizobium with } \\
\text { Trifolium alexandrinum may increase final } \\
\text { yield }\end{array}$ & Shamseldin et al. (2016) \\
\hline Rhizobium anhuiense & $\begin{array}{l}R \text {. anhuiense is the main symbiont for beach } \\
\text { pea (Lathyrus maritimus or Lathyrus } \\
\text { japonicus) rhizobia on the seashore line of } \\
\text { China and Japan }\end{array}$ & Li et al. (2016) \\
\hline Rhizobium (VR-1 and VA-1) & $\begin{array}{l}\text { Inoculation of host-specific fly-ash-tolerant } \\
\text { Rhizobium strain with plants ha positive role } \\
\text { in improving plant growth }\end{array}$ & Chaudhary et al. (2011) \\
\hline Rhizobium & $\begin{array}{c}\text { Rhizobial bacteria can mitigate the negative } \\
\text { impacts of excess arsenic (As) in legume- } \\
\text { rhizobium symbiosis }\end{array}$ & Reichman (2007) \\
\hline Rhizobium & $\begin{array}{c}\text { Rhizobium strains in Sporobolus robustus } \\
\text { Kunth's rhizosphere has ability to act as a nurse } \\
\text { plant to improve seedlings recruitment of } \\
\text { Prosopis juliflora and Vachellia seyal in saline } \\
\text { soils }\end{array}$ & Fall et al. (2019) \\
\hline Rhizobium & $\begin{array}{c}\text { Nodulation and nitrogen fixation of guar } \\
\text { (Cyamopsis tetragonolobus } \mathrm{L} \text {. Taub.)) } \\
\text { significantly, increase with indigenous } \\
\text { Rhizobium in field conditions. Rhizobium } \\
\text { inoculation also can have positive effects on } \\
\text { productive qualitative traits of guar such as } \\
\text { Galactomannan content }\end{array}$ & $\begin{array}{l}\text { Thapa et al. (2018) } \\
\text { Gresta et al. (2019) }\end{array}$ \\
\hline Rhizobium PEPV16 & $\begin{array}{l}\text { Inoculation with Rhizobium strains is a } \\
\text { promising technique to improve the content of } \\
\text { several bioactive compounds of strawberries }\end{array}$ & Flores-Felix et al. (2018) \\
\hline $\begin{array}{l}\text { R. leguminosarum } \\
\text { R. fabae } \\
\text { R. laguerreae } \\
\text { R. anhuiense }\end{array}$ & $\begin{array}{c}\text { Nodulation of Vicia faba L. with these } \\
\text { Rhizobium increase sustainable crop } \\
\text { production }\end{array}$ & $\begin{array}{l}\text { Torres et al. (2012) } \\
\text { Saidi et al. }(2014) \\
\text { Youseif et al. }(2014) \\
\text { Zhang et al. (2015) } \\
\text { Belhadi et al. (2018) }\end{array}$ \\
\hline Rhizobium BMBS (Diazotrophic bacterium) & $\begin{array}{c}\text { Rhizobium BMBS and Arbuscular } \\
\text { mycorrhizal fungi ( Glomus intraradices) } \\
\text { primed suggested as a bioprotectant against } \\
\text { Spodopteralitura in blackgram }\end{array}$ & Selvaraj et al. (2020) \\
\hline Rhizobium freirei PRF 81 & $\begin{array}{c}\text { It has adaptive response to acid } \mathrm{pH} \text { and this } \\
\text { acid tolerance decrease internal acidification } \\
\text { show the broad range of metabolic pathways of } \\
\text { this Rhizobium }\end{array}$ & $\begin{array}{l}\text { Hungria et al. (2000) } \\
\text { Tullio et al. (2019) }\end{array}$ \\
\hline Rhizobium & $\begin{array}{l}\text { Rhizobium inoculation can improve uptake of } \\
\text { water, macro and micro nutrients in legumes } \\
\text { such as soybean }\end{array}$ & $\begin{array}{c}\text { Gao et al. (2010) } \\
\text { Nyoki and Ndakidemi (2018) }\end{array}$ \\
\hline
\end{tabular}

Table 6. The most important rhizobia nodulated with Phaseolus vulgaris

\begin{tabular}{|l|c|}
\hline \multicolumn{1}{|c|}{ Rhizobium } & Reference \\
\hline $\begin{array}{l}\text { Rhizobium etili, Rhizobium tropici, Rhizobium } \\
\text { leguminosarum bv. phaseoli, Rhizobium gallicum, } \\
\text { Rhizobium azibense }\end{array}$ & Mnasri et al. (2014) \\
\hline Rhizobium freirei & Dall'Agnol et al. (2013) \\
\hline Rhizobium mesoamericanum & Lopez-Lopez et al. (2012) \\
\hline Sinorhizobium meliloti & Zurdo-Pineiro et al. (2009) \\
\hline Sinorhizobium americanum & Mnasri et al. (2012) \\
\hline Bradyrhizobium sp. & Han et al. (2005) \\
\hline R. etli in the South and Middle Americas & Amarger (2001) \\
\hline R. etli in Europe & Garcia-Fraile et al. (2010) \\
\hline
\end{tabular}




\begin{tabular}{|l|c|}
\hline R. etli in Jordan & Tamimi and Young (2004) \\
\hline R. tropici in regions with high temperature and acid soils & Martinez-Romero et al. (1991) \\
& Anyango et al. (1995) \\
\hline R. phaseoli and R. etli in Africa & Grange and Hungria (2004) \\
\hline R. leguminosarum, . etli and Rhizobium sp. II or IV & Aserse et al. (2012) \\
\hline
\end{tabular}

\section{Agrobacterium}

The genus Agrobacterium was created by Conn (1943) within the family Rhizobiaceae together with the genus Rhizobium (Frank, 1889). Agrobacterium tumefaciens was first isolated from the gall tissue and recognized as the cause of crown gall disease (Smith and Townsend, 1907). Bacteria belong to Agrobacterium group are recognized as symbionts and pathogen of specific plants (Long et al., 1989; Goodner et al., 2001), and known as intracellular bacteria in the hyphae of a few endophytic fungal species (Sharma et al., 2008; Baltrus et al., 2017; Guo et al., 2018). It has extraordinary capacity to transfer its genetic material to host cell which makes it evolve from phytopathogen to a powerful transgenic vector (Ziemienowicz 2014; Guo et al., 2019). Agrobacterium tumefaciens, is a gram-negative, soil-born phytopathogenic bacterium which is called a nature's engineer because of its ability to genetically transform the host by transferring a DNA fragment ( $T$ DNA) from its Ti plasmid to host-cell genome (Guo et al., 2009; Guo et al., 2011; Nester, 2015; Guo et al., 2017; Sun et al., 2018; Wixom et al., 2018). Agrobacterium tumefaciens-mediated transformation (ATAT) is an effective genetic transformation method in recent 20 years (Gu et al., 206; Moon et al., 2008; Shao et al., 2015; Yang et al., 2018), which is a member of the alpha-Proteobacteria which a resident of the soil and rhizosphere (Hanana et al., 2018; Li et al., 2018; Nathoo et al., 2019; Niazian et al., 2019). ATMT works well with different fungal materials such as spores, mycelia, and gill tissues of mushroom (Chen et al., 2000; Mulllins et al., 2001; Park et al., 2013), which makes it appropriate for fungal genetic manipulation (Xu et al., 2016; Idnurm et al., 2017; Long et al., 2018). In pharmaceutical studies, this technique has been also used to produce various proteins, and general functional studies of plant proteins (O’Neill et al., 2008; Jones, 2016). Several studies introduced ATMT as an initiative bio-transformation system which may provide new insights into fungal pathogenesis, pigmentation, sporulation, and antibiotic resistance (Jeon et al., 2007; Huser et al., 2009; Mischielse et al., 2009; Zhang et al., 2011). Along with A. tuerfaciens, Agrobacterium rhizogenes, has been used to affect genetic transformation in many plants for several years (Bahramnejad et al., 2017). Agrobacterium rhizogenes - mediated transformations has a lot of advantages such as fast growth rates, ease of maintenance, genetic stability, large scale biomass production which does not need external usage of phytohormones and ability to synthesize a broad array of valuable secondary metabolites (Srivastava and Srivastava, 2007; Chandra and Chandra, 2011). Agrobacterium rhizogenes includes a root-inducing (Ri) plasmid (Chen et al., 2018) which contains root locus (rol) genes in the T-DNA region consist of rolA, rolB, rolC, and rolD (Christey and Braun, 2005). Hairy root cultures have been studied for application as pharmaceuticals, nutraceuticals, food additives and cosmetic (Srivastava and Srivastava, 2007; Chandra and Chandra, 2011). Hairy root caused by Agrobacterium rhizogenes and cane gall caused by A. rubi (Pacurar et al., 2011). The most important characteristics of Agrobacteria is indicated in Table 7. The most important species included in the genus Agrobacterium and species causing tumors and hair roots in other genera of family Rhizobiaceaeare presented in Table 8. Hairy roots benefits in some reported samples are shown in Figure 10. Different Agrobacterium for different plants is presented in Table 10. 
Table 7. The most important characteristics of Agrobacteria

1- A group of Gram-negative, non-spore-forming soil bacteria, mainly isolated from abnormal proliferating plant tissues

2- They belong to a large family of plant-associated bacteria, namely Rhizobiaceae, which include Rhizbonium and Sinorhizobium, which are nitrogen-fixing symbiotic bacteria

3- They are able to catabolize a large variety of metabolites, and they can show chemotactic behavior for some plant exudates

4- The genome composition of Agrobacterium tumefaciens is circular chromosome secondary linear chromosome

5- The genome composition of Agrobacterium radiobacter is circular chromosome four plasmids

6- The genome composition of Agrobacterium vitis is circular chromosome, chromosome, and five plasmids.

7- Agrobacterium-induced tumors in nature which have been documented on more than 1000 different plant species, belonging to most of the families of the dicotyledonous plants

8- In researches related to general cell and molecular biology, Agrobacterium interactions with its host cells have emerged as an important experimental system

9- Classification of different species of Agrobacterium is predominantly based on their phytopathogenic properties

10- Under optimal laboratory conditions, Agrobacteria are motile (with one to six flagella), aerobic, rod-shaped bacteria, with a slow generation time (1.5 to several hours)

11- T-DNA and the virulence (vir) region are two important genetic regions on the Ti plasmid which are essential for Agrobacterium to transfer DNA to plant cells

12- Agrobacterium Tiplasmif consider as gene vector for plant genetic engineering

13- Agrobacterium mediated gene transfer is controlled by different factors such as bacterial factors, host and environmental origin

14- Agrobacterium has been successfully applied for various economically and horticulturally important monocot and dicot species transformation via standard tissue culture and in planta transformation techniques

15- Gene transfer from Agrobacterium to plant cells consist of five important steps which are, induction of the bacterial virulence system, generation of T-DNA complex, transfer of T-DNA from Agrobacterium to the host cell nucleus, integration of T-DNA into the plant genome, and expression of T-DNA genes

16- The most important factors which impact Agrobacterium mediated plant transformations are explants type, vector plasmid, bacterial strain, composition of culture medium, temperature of co-cultivation, time of cocultivation, Agrobacterium density, $\mathrm{pH}$ of co-cultivation medium, antibiotics, chemicals, surfactants and selected markers

17- The ability of infecting plants is because of the possession of large plasmids by both bacterial species, known as $\mathrm{Ti}$ and Ri plasmids for both $A$. tumefaciens and $A$. rhizogenes

Table 8. The most important species included in the genus Agrobacterium and species causing tumors and hair roots in other genera of family Rhizobiaceae (Flores-Felix et al., 2020)

\begin{tabular}{|l|l|}
\hline \multicolumn{1}{|c|}{ Genus } & \multicolumn{1}{c|}{ Species } \\
\hline Agrobacterium & $\begin{array}{l}\text { A. radiobacter, } \text { A. tumerfaciens, A. rubi, A. larrymoorei, A. albertimagni, A. fabrum, } \\
\text { A. pusense, A. nepotum, A. skierniewicense, A. arsenijevicii, A. deltaense, A. salinitolerans, } \\
\text { A. bohemicum, A. rosae }\end{array}$ \\
\hline Allorhizobium & A. vitis \\
\hline Rhizobium & R. rhizogenes, R. tumorigenes \\
\hline
\end{tabular}


Table 9. Hairy roots reported in some crops

\begin{tabular}{|l|c|}
\hline \multicolumn{1}{|c|}{ Benefits of hairy roots } & References \\
\hline Increase the amount of saponin in Bacopamonnieri & Majumdar et al. (2011) \\
\hline $\begin{array}{l}\text { Enhance the amount of anthroquinones in Polygonum } \\
\text { multiflorum }\end{array}$ & Thiruvengadam et al. (2014a) \\
\hline Increase total phenolic content in Solanum lycopersicum & Singh et al. (2014) \\
\hline Increase polyphenols in Momordica charantia & Thiruvengadam et al. (2014b) \\
\hline $\begin{array}{l}\text { Enhance the amount of glucosinolates in Arabidopsis } \\
\text { thaliana }\end{array}$ & Kastell et al. (2015) \\
\hline $\begin{array}{l}\text { Increase phenolic compounds in Momordica dioica } \\
\text { Roxb. ex. Willd }\end{array}$ & Thiruvengadam et al. (2016) \\
\hline
\end{tabular}

Table 10. Different Agrobacterium for different plants

\begin{tabular}{|c|c|c|}
\hline Different Agrobacterium isolated from nature & & Reference \\
\hline Agrobacterium tumefaciens & $\begin{array}{l}\text { *A gram-negative and rod-shaped plant } \\
\text { pathogen belonging to the family Rhizobiacea. } \\
\text { It can transfer transferred DNA (T-DNA), } \\
\text { which is located in its tumor-inducing (Ti) } \\
\text { plasmid, into the chromosome of the target } \\
\text { cells at random sites. } \\
\text { *Strain Chry5 is hypervirulent on many plants, } \\
\text { especially soybean. Tumors induced by Chry5 } \\
\text { contain a novel opine called chrysopine. } \\
\text { Agrobacterium tumefaciens and its Ti plasmid } \\
\text { have been extensively used as a vector to create } \\
\text { transgenic plants and fungi. } \\
\text { *It is specific for NAD }{ }^{+} \text {as a cofactor, but } \\
\text { accepted both D-galacturonic acid (GalA) and } \\
\text { D-glucuronic acid (GlcA) as substrates with } \\
\text { similar affinities, and the reaction product is } \\
\text { probably the hexaro-lactone, which } \\
\text { spontaneously hydrolyzes. } \\
\text { *In Soybean, the hypervirulent Agrobacterium } \\
\text { tumefaciens strains KYRT1 proved to be a } \\
\text { better transformer than EHA105 and } \\
\text { LBA4404 }\end{array}$ & $\begin{array}{l}\text { Van Larebeke et al. (1975) } \\
\text { Bush and Pueppe (1991) } \\
\text { Dessaux et al. (1993) } \\
\text { Chilton et al. (1995) } \\
\text { Palanichelvam et al. (2000) } \\
\text { Satyavathi et al. (2002) } \\
\text { Dang and Wei (2007) } \\
\text { Shao et al. (2018) } \\
\text { Murugan etal. (2019) } \\
\text { Xiao et al. (2020) }\end{array}$ \\
\hline $\begin{array}{l}\text { Agrobacterium sp. H13-3 (Rhizobium lupine } \\
\text { H13-3) }\end{array}$ & $\begin{array}{l}{ }^{*} \text { It is a soil bacterium isolated from the } \\
\text { rhizosphere of Lupiunus luteus. It is unable to } \\
\text { nodulate Lupinus under laboratory } \\
\text { conditions. Its highly conserved circular } \\
\text { chromosome ( } 2.82 \mathrm{Mb}) \text { mainly encodes } \\
\text { housekeeping functions characteristic for an } \\
\text { aerobic, heterotrophic bacterium. It also posses } \\
\text { a linear chromosome ( } 2.15 \mathrm{Mb}) \text { which is } \\
\text { related to its reference replicon and features } \\
\text { chromosomal and plasmid-like properties. It } \\
\text { has been reported that a tumor-inducing Ti- } \\
\text { plasmid is missing in the sequenced strain } \\
\text { H13-3 indicating that it is a non-virulent } \\
\text { isolate }\end{array}$ & $\begin{array}{c}\text { Balassa (1957) } \\
\text { Gabor (1965) } \\
\text { Wibberg et al. (2011) }\end{array}$ \\
\hline Agrobacterium rhizogenes & $\begin{array}{c}{ }^{*} \text { Hydroponically-inoculated of Daturainnoxia } \\
\text { plants with Agrobacterium rhizogenes can } \\
\text { increase growth and alkaloid metabolism } \\
\text { which may be more useful for successful } \\
\text { specialized metabolite bioproduction in } \\
\text { greenhouses } \\
\end{array}$ & Vu et al. (2018) \\
\hline Agrobacterium fabrum & $\begin{array}{l}\text { *It has evolved a mechanism to deliver genes } \\
\text { into cell of wounded plant tissue. It is } \\
\text { considered as the suitable model organism, } \\
\text { and a widely used vector for plant } \\
\text { transformation }\end{array}$ & $\begin{array}{c}\text { Deropp (1951) } \\
\text { Klee et al. }(1987) \\
\text { Zupan et al. }(2000) \\
\text { Bai et al. }(2016)\end{array}$ \\
\hline Agrobacterium-mediated transformation & ${ }^{*}$ A common and convenient method to & Kobayashi and Uchimiya (1989) \\
\hline
\end{tabular}




\begin{tabular}{|c|c|c|}
\hline & $\begin{array}{l}\text { integrate gene into plant at higher efficiencies. } \\
\text { This method could be providing a } \\
\text { regeneration of transgenic plant from leaf and } \\
\text { stem segments to increase biomass, chemical } \\
\text { components yield and quality of plants. } \\
\text { Genetic transformation methods are divided } \\
\text { into direct gene transfer and indirect gene } \\
\text { transfer methods according to the transferring } \\
\text { procedure. }\end{array}$ & $\begin{array}{c}\text { Vardi et al. (1990) } \\
\text { Hidaka and Omura (1993) } \\
\text { Yao et al. }(1996) \\
\text { Wang et al. }(1998) \\
\text { Dai et al. }(2001) \\
\text { Niedz et al. }(2003) \\
\text { Gao et al. }(2008) \\
\text { Shewry et al. }(2008) \\
\text { Ozawa (2009) } \\
\text { He et al. (2010) } \\
\text { Ozawa and Takaiwa (2010) } \\
\text { Abdallat et al. (2011) } \\
\text { Dewir et al. (2015) } \\
\text { Koetle et al. }(2015) \\
\text { Nabeshima et al. (2016) } \\
\text { Huang et al. (2017) } \\
\text { Shivani and Tiwari (2019) } \\
\text { Singh et al. (2019) }\end{array}$ \\
\hline Agrobacterium tumefaciens & $\begin{array}{l}{ }^{*} \text { The Agrobacterium tumefaciens-mediated } \\
\text { transformation (ATMT) technique has been } \\
\text { used in randomized mutagenesis experiments, } \\
\text { which has higher efficiency and percentage of } \\
\text { single-copy patterns of T-DNA added into the } \\
\text { fungal recipient. ATMT may be used as a } \\
\text { molecular tool for different agronomical } \\
\text { plants. }\end{array}$ & $\begin{array}{l}\text { Mullins and Kang (2001) } \\
\text { Leclerque et al. (2004) } \\
\text { Sugui et al. (2005) } \\
\text { Michielse et al. (2008) } \\
\text { Talhinhas et al. (2008) } \\
\text { Islam et al. (2012) } \\
\text { Jiang et al. (2013) } \\
\text { Li et al. (2019) }\end{array}$ \\
\hline
\end{tabular}

\section{Bradyrhizobium}

Distribution of rhizobial species is significantly influenced by geographical isolation and leguminous hosts (Keller et al., 2018; Ji et al., 2019). Various leguminous woody plants and herbs such as soybean, peanut, and cowpea, nodulated by bacteria belonging to the genus Bradyrhizobium (Moulin et al., 2004; Degefu et al., 2017). Slow-growing rhizobia classified within the genus Bradyrhizobium, including B. japonicum, B. lupine, B. canariense and B. elkanii species have role in nodulating of lupines species (Peix et al., 2015; Shamseldin et al., 2017; Stepkowski et al., 2018; Mellal et al., 2019). B. japonicum also recommend as a plant growthpromoting rhizobacterium for various plant species in sites contaminated with heavy metals (Reichman, 2014). The positive role of Bradyrhizobium - legume nodulation in maintaining plant community structure and restoration of degraded ecosystems has been reported in Southwest China (Liu et al., 2015). Minimizing deleterious effects of exposing plants to composted tannery sludge because of inoculation with Bradyrhizobium is an important way to ensure plant growth and productivity (Moraes et al., 2016). Improving growth and symbiotic performance of lupin under drought stress is reported by HTC-based Bradyrhizobium sp. (Egamberdieva et al., 2017). Li et al. (2019) proposed isolated Bradyrhizobium nanningense sp. nov., Bradyrhizobium guangzhouense sp. nov. and Bradyrhizobium zhanjiangense sp. nov. of peanut in Southeast China. B. japonicum, B. elkanii and B. liaoningense are famous isolated Bradyrhizobium from Glycine max nodules in Japan, the USA and China, respectively (Jordan, 1982; Kuykendall et al., 1992; Xu et al., 1995). B. pachyrhizi and B. jicamae are isolated Bradyrhizoium from Pachyrhizuserosus nodules in Costa Rica and Honduras, respectively (Ramirez-Bahena et al., 2009), and B. Cytisi and B. rifense are isolated Bradyrhizobium from Cytisusvillosus nodules in Morocco (Chahboune et al., 2011; Chahboune et al., 2012). Inoculation with nodulatin B. japonicum is important agricultural practice which can increase the content of bioactive metabolites in Glycine Max seeds (Silva et al., 2013). Various benefits and advantages of Bradyrhizobium are shown in Table 11. 
Table 11. Various benefits and advantages of Bradyrhizobium

\begin{tabular}{|c|c|c|}
\hline Bradyrhizobium & Benefits and advantages & References \\
\hline Bradyrhizobium & $\begin{array}{c}\text { Peanut (Arachis hypogeae L.) } \\
\text { nodulated by the genus } \\
\text { Bradyrhizobium. }\end{array}$ & Fabra et al. (2010) \\
\hline $\begin{array}{l}\text { Bradyrhizobium and fungal } \\
\text { endophyte Phomopsis liquidambari }\end{array}$ & $\begin{array}{c}\text { P. liquidambari inoculation may } \\
\text { increase flavonoids synthesis-related } \\
\text { enzymes activities and its } \\
\text { contribution enhances peanut- } \\
\text { bradyrhizobium interaction, yield and } \\
\text { nodulation. }\end{array}$ & Zhang et al. (2016) \\
\hline $\begin{array}{l}\text { Bradyrhizobium japonicum E109 } \\
\text { and Azospirillum brasilenseAz39 }\end{array}$ & $\begin{array}{c}\text { B. japonicum } \mathrm{E} 109 \text { and } A \text {. } \\
\text { brasilenseAz39 inoculation is the } \\
\text { useful practice to improve both } \\
\text { growth and yield of soybean exposed } \\
\text { to As }\end{array}$ & Armendariz et al. (2019) \\
\hline Bradyrhizobium japonicum E109 & $\begin{array}{l}\text { It is able to produce indole acetic acid } \\
\text { (IAA), gibberellins }\left(\mathrm{GA}_{3}\right) \text { and zeatin } \\
(\mathrm{Z}) \text { which can lead to significant } \\
\text { morphological and physiological } \\
\text { changes in maize and soybean young } \\
\text { seed tissues }\end{array}$ & $\begin{array}{l}\text { Cassan et al. (2009) } \\
\text { Garcia et al. }(2017)\end{array}$ \\
\hline Bradyrhizobium japonicum & $\begin{array}{l}\text { B. japonicum can be considered as an } \\
\text { attractive selection for remediation of } \\
\text { fungicide polluted soils and to } \\
\text { concurrently increase greengram } \\
\text { production especially in stressed } \\
\text { environment. }\end{array}$ & Shahid and Saghir Khan (2019) \\
\hline $\begin{array}{l}\text { Bradyrhizobium japonicum } \\
\text { USDA119 }\end{array}$ & $\begin{array}{l}\text { It can be considered as a model } \\
\text { organism for screening pollutants for } \\
\text { toxicity against a soil microbial } \\
\text { community }\end{array}$ & Shah and Subramaniam (2018) \\
\hline Bradyrhizobium & $\begin{array}{l}\text { It has been used for eco-toxicity } \\
\text { studies such as measuring toxicity } \\
\text { include chlorimuron-ethyl, heavy } \\
\text { metals, metal-rich sewage sludge, } \\
\text { acidity, phospate, herbicides, osmotic } \\
\text { stress, nanoparticles and etc. }\end{array}$ & $\begin{array}{c}\text { Keyser and Munns (1979) } \\
\text { Moorman (1986) } \\
\text { Kinkle et al. }(1987) \\
\text { Zawoznik and Tomaro (2005) } \\
\text { Soria et al. (2006) } \\
\text { Reichman (2014) }\end{array}$ \\
\hline Bradyrhizobium yuanmingense & $\begin{array}{l}\text { It is a potent rhizobium for the } \\
\text { development of groundnut inoculants } \\
\text { in Ghana. }\end{array}$ & Osei et al. (2018) \\
\hline $\begin{array}{l}\text { Bradyrhizobium canariense and } \\
\text { Bradyrhizobium japonicum }\end{array}$ & $\begin{array}{c}\text { These two Bradyrhizobium are } \\
\text { dominant rhizobium species in root } \\
\text { nodules of lupin and serradella plants } \\
\text { in Europe }\end{array}$ & Stepkowski et al. (2011) \\
\hline Bradyrhizobium algeriense & $\begin{array}{l}\text { B. algeriense is able to establish } \\
\text { effective symbioses with Retama } \\
\text { raetam, Lupinus micranthus, Lupinus } \\
\text { albus, and Genista numidica }\end{array}$ & Ahnia et al. (2018) \\
\hline Brazilian Bradyrhizobium & The Brazilian Bradyrhizobium & Bellini et al. (2019) \\
\hline
\end{tabular}




\begin{tabular}{|c|c|c|}
\hline japonicum & $\begin{array}{l}\text { japonicum strain CPAC-15 } \\
(=\text { SEMIA 5079) is an important } \\
\text { intermediate for semi-synthesis of } \beta \text { - } \\
\text { lactam antibiotics such as penicillins, } \\
\text { cephalosporins and amoxicillin. }\end{array}$ & \\
\hline Bradyrhizobium diazoefficiens & $\begin{array}{l}\text { B. diazoefficiens strain USDA110 has } \\
\text { XoxF, a lanthanides-dependent } \\
\text { MDH, which has the ability of } \\
\text { methanol oxidation and is induced by } \\
\text { methanol/lanthanaides. Lanthanide } \\
\text { consider as the key factors in } \\
\text { methanol utilization by the strain. }\end{array}$ & $\begin{array}{l}\text { Liu et al. (2018) } \\
\text { Wang et al. (2019) }\end{array}$ \\
\hline $\begin{array}{l}\text { Bradyrhizobium cytisi and } \\
\text { Bradyrhizobium rifense }\end{array}$ & $\begin{array}{l}\text { The strains isolated from } \text { Astragalus } \\
\text { algarbiensis clustered with } B \text {. cytisi } \\
\text { and } B \text {. rifense }\end{array}$ & Alami et al. (2019) \\
\hline Bradyrhizobium canariense & $\begin{array}{c}\text { The Mimosid tree Leucaena } \\
\text { Leucocephala can be nodulated by } \\
\text { symbiovargenistearum of } \\
\text { Bradyrhizobiumcanariense }\end{array}$ & Ramirez-Bahena et al. (2020) \\
\hline
\end{tabular}

\section{Herbaspirillum}

Herbaspirillum seropedicae which can colonize a variety of higher plants, are diazotrophic endophytes; moreover, they have role in carbon catabolism by utilizing diverse carbon substrates and employ the EntnerDoudoroff route (Baldani et al., 1986; Falk et al., 1986; Catalan et al., 2007). This endophytic diazotrophic $\beta$ Proteobacterium nitrogen-fixing bacterium has association with important agricultural plants such as rice, maize, sorghum, sugarcane and wheat for nitrogen fixation (Galvao et al., 2004; Chaves et al., 2009; Serrato et al., 2012; Govarthanan et al., 2014; Dos Santos et al., 2017). Its capacity of convert $\mathrm{N}_{2}$ to $\mathrm{NH}_{3}$ through biological nitrogen fixation has made it a plant growth-promoting bacterium (Pessoa et al., 2016). NifA protein regulates nitrogen fixation in $H$. seropedicae at the transcriptional level (Oliveira et al., 2012), NifA itself is a member of the enhancer binding protein family with three structural domains (Studholme and Dixon, 2003). Ammonium ions through a mechanism involving its $\mathrm{N}$-terminal domain control the activity of NifA, and $\mathrm{N}$ terminal domain inhibits NifA-dependent transcriptional activation by an inter-domain cross-talk between the catalytic domain of the NifA protein and its regulatory $\mathrm{N}$-terminal domain in response to fixed nitrogen (Monteiro et al., 2001). The activity of NifA is negatively influenced by oxygen (Monteiro et al., 1999; Souza et al., 1999; Oliveira et al., 2009), but interaction with Glnk positively influence it, and binding of 2-OG and MgATP to Glnk are very important for NifA activation (Stefanello et al., 2020). Its oxygen sensitivity may attribute to a conserved motif of cysteine residues in NifA which spans the central AAA+ domain and the interdomain linker which connects the AAA + domain to the C-terminal DNA binding domain (Oliveira et al., 2009). GlnK, a PII signaling protein which monitors intracellular levels of key metabolite 2-oxoglutrate (2OG) and works as an indirect sensor of the intracellular nitrogen status (Monteiro et al., 1999; Monteiro et al., 2003; Dixon and Khan, 2004; Noindorf et al., 2011; Oliveira et al., 2012). In the Betaproteobacterium $H$. seropedicae, the sensing of environmental signals is performed by the NifA protein itself, and the NifL protein is absent (Dixon and Kahn, 2004). Colonization sites detected for Herbaspirillum seropedicae ( $\beta$ ), and Herbaspirillum rubrishubalbicans ( $\beta$ ) are indicated in Table 12. 
Table 12. Colonization sites detected for Herbaspirillum seropedicae ( $\beta$ ), and Herbaspirillum rubrishub albicans $(\beta)$

\begin{tabular}{|c|c|c|}
\hline \multirow{2}{*}{$\begin{array}{l}\text { Herbaspirillum } \\
\text { seropedicae }(\beta)\end{array}$} & Sugar cane & $\begin{array}{l}\text { Roots: Intercellular, Intracellular in cortex, Xylem vessels } \\
\text { Shoots: Intracellular in xylem vessels }\end{array}$ \\
\hline & Sorghum & Shoots: Intracellular, Confined to xylem vessels at point of injection \\
\hline \multirow{2}{*}{$\begin{array}{c}\text { Herbaspirillum } \\
\text { rubrishub } \\
\text { albicans }(\beta)\end{array}$} & Sugar cane & $\begin{array}{l}\text { Shoots: In leaves, Intercellular, Intracellular in substomatal cavities, } \\
\text { Mesophyll, Xylem vessels }\end{array}$ \\
\hline & Sorghum & Shoots: In leaves, Intracellular in xylem vessels \\
\hline
\end{tabular}

Pedrosa et al. (2001) found that nitrogen fixation in H. seropedicae (of the $\beta$-subgroup of Proteobacteria), has regulatory features in common with Klebsiella pneumonia (of the $\gamma$-subgroup and with rhizobia and Azospirillum brasilense (of the $\alpha$-subgroup), at the level of NifA expression, and at the level of control of NifA by oxygen, respectively. Hu et al. (2020) found observed that nirS denitrifying bacteria Herbaspirillum and Pseudomonas were the dominant species in declined P. crispus sediment. NtrC regulates several operons involved in nitrogen assimilation in Herbaspirillum seropedicae (Twerdochlib et al., 2003). Lubambo et al. (2013) found that Herbaspirillum seropedicae GlnB (Glnb-Hs) is a signal transduction protein which has role in controlling of nitrogen, carbon, and energetic metabolism.

\section{Sinorhizobium}

Sinorhizobium meliloti is a Gram-negative soil bacterium which accumulate $N$-acetylglutaminyl glutamine amide and trehalose in hyperosmolarity (Brique et al., 2010; Ferroni et al., 2012), and it survive needs developing active adaptive mechanisms quite different in humidity and aridity (Miller and Wood, 1996). Two famous phylogenetically closely-related species are Sinorhizobium (Ensifer) meliloti and S. medicae (Rome et al., 1996; Roumiantseva et al., 1999; Young et al., 2001), live free in soil or in symbiosis with leguminous plants and perform nitrogen fixation (Ferri et al., 2010; Wibberg et al., 2013; Dohlemann et al., 2016). Their genomes show multipartite architecture (Roumiantseva et al., 1999), and high genetic similarity (Rome et al., 1996). The endogenous compatible solutes in $S$. meliloti are the amino acid glutamate, the dipeptide $N$ acetylglutaminyl glutamine amide (NAGGN) and the disaccharide trehalose ( $\alpha$ Glucose- $(1 \biguplus 1)-\alpha$ Glucose) (Smith and Smith, 1989; Breedveld et al., 1990; Botsford and Lewis, 1990). The S. meliloti genome is composed of a chromosome $(3.65 \mathrm{Mb})$, and the megaplasmidspSyma $(1.35 \mathrm{mb})$ and $\mathrm{pSymB}(1.68 \mathrm{Mb})$ (Galibert et al., 2001). It produces sizable quantities of synthesize polyhydroxyalkanoates (PHA) and exopolysaccharides (EPS) (Tombolini and Nuti, 1989; Reinhold et al., 1994; Saranya Devi et al., 2012). Shamala et al. (2014) found that free living cells of $S$. meliloti influenced by fermentation conditions like $\mathrm{pH}$, dissolved oxygen level, amount of carbon and nitrogen. It has been reported that all strains of Sinorhizobium meliloti do not stimulate plant growth of alfalfa cultivar in a similar extent (Zeng et al., 2007). Tu et al. (2011) suggests that $S$. meliloti is promising in biodegradation capability and metabolic intermediate of polychlorinated biphenyls. The survival and persistence of $S$. meliloti was increased by alfalfa cultivation and enhanced soil fertility (Bhattacharya and Das, 2003; Da and Deng, 2003). This nitrogen-fixing $\alpha$ proteobacterium is able to biosynthesize osmoprotectant glycine betaine from choline sulfate via a metabolic pathway which starts with the enzyme choline- $O$-sulfatase (Sanchez-Romero and Olguin, 2015). The nifA gene of $S$. meliloti is the most important regulator which activates the expression of fix genes and a bunch of nif (Better et al., 1984; Szeto et al., 1984; Earl et al., 1987). NifA plays a regulatory role in multiple cellular process, and it may nifA null mutant may induce small white invalid nodules in the roots of host plant (Gong et al., 2007). The rhizobia which nodulate the tropical leguminous trees Acacia Senegal and Prosopis chilensis are Sinorhizobium arboris and S. kostiense (Zhang et al., 1991; Nick et al., 1999; Nowak et al., 2004). The first strains of the species described as nodulating Lotus was $S$. meliloti symbiovar lancerottense (Leon-Barrios et al., 2017). Nodulation and mycorrhizal dependency (MD) in each plant genotype vary on the basis of Sinorhizobium strain and arbuscular mycorrhizal (AM) fungi involved (Vazquez et al., 2001). Several studies 
recognized Sinorhizobium meliloti 1021 as a model organism for the study of symbiotic nitrogen fixation with legume plant hosts such as alfalfa, barrel medic, and some other plants of the Medicago and Melilotus genera (Jones et al., 2007b; Gibson et al., 2008). Its important transducing phage ФM12 (Brewer et al., 2014) was originally isolated from a commercial rhizobial seed inoculants prepared for field crop use on alfalfa (Finan $e t$ al., 1984). Carbohydrate cycling in $S$. meliloti is independent of the gluconate bypass and also observed on fructose which makes this bacterium different from those of alginate-synthesizing species (Gosselin et al., 2001).

Sinorhizobium meliloti belongs to the alpha class of the Gram-negative proteobacteria (Alphaproteobacteria). For a long time, it has been studied to infect roots of leguminous plants especially the genus Medicago (M. sativa and M. truncatula) (Xue and Biondi, 2019). Nod factors produced by bacteria and the flavonoids secreted into the rhizophere by the plants after the first contact between bacteria and plants (Cooper, 2007; Liu and Murray, 2016). Nod factors modulate the entry of the bacteria into the plant tissue which occurs following the formation of a modified radical root hair (Shaw and Long, 2003; Sieberer et al., 2005). Then, the root hair traps a few $S$. meliloti cells, which penetrate inside the root tissue and induce the formation of an infection thread which is sealed after the entrance of few bacteria (Jones and Walker, 2008). After that, bacteria divides, reach the internal tissue which will host the future bacteroids. Then, bacteria are introduced into the plant cell by invagination of the plant cell membrane, which may lead to bacterium being surrounded by a plant derived membrane. This prokaryotic cell called a symbiosome (Jones et al., 2007). Even without the presence of legumes, $S$. meliloti lives in the soil are free-living organism (Carelli et al., 2000). $S$. meliloti is able to colonize the whole plant and the plant may have evolved a way to induce a terminal differentiation which may lead to blocking bacteria duplication and preventing uncontrolled colonization of the plant (Xue and Biondi, 2019). A S. meliloti bacteroid has two important features: a) Nitrogen fixation, b) Generating new cells once the nodule enters a senescent state (Kereszt et al., 2011). Specific regulators of Fix and Nif control the bacteroid metabolism (Jones et al., 2007). The activity of CtrA which has role in cell cycle regulation across alphaproteobacterial species, may regulate coordinates DNA replication, cell division and presumably bacteroid differentiation (Brilli et al., 2010). Ctr A is essential for viability and controlling essential functions such as cell division, DNA replication and DNA methylation in S. meliloti (Xue and Biondi, 2019). Ctr A has can also considered as a crucial factor during bacteroid differentiation (Xue and Biondi, 2019). Peptides, such as NCR247, may be targeting directly or indirectly CtrA with its complex regulatory apparatus (Xue and Biondi, 2019).

\section{Conclusions}

Soil bacteria which are known as rhizobia (in roots and rarely stems) can associate with some plants (especially from the Leguminosae) and trees, forming specialized organs known as nodules. The ability of adaptation of Rhizobia in diverse environment namely soil, rhizosphere and grown within legume roots may lead to nitrogen fixation, in a complicated process which contain a coordinated exchange of signal between the symbionts and plants. Nodulation also varied on the basis of the species and site. There are almost 50 noduleforming bacterial species within the genera. The most important alphaproteobacteria are 1) Allorhizobium included, Aminobacter, Azorhizobium, Bradyrhizobium, Devosia, Mesorhizobium, Methylobacterium, Microvirga, Neorhizobium, Ochrobactrum, Phyloobacterium, Rhizobium, Shinella, Sinorhizobium (Ensifer), 2) Betaproteobacteris, consists of Cupriavidus, Paraburkholderia and Trinickia, and 3) Gamaproteobacteria. Rhizobium improves sustainable production by boosting organic nitrogen content. Notable parameters which have been related to successful establishment of the symbiotic interaction are chemotaxis of the bacteria towards the roots, root colonization and its hair deformation, infection thread formation, and rapid division or root cortex cells. Rhizobia produce Nod factors during the early development of nodules upon perception of flavonoid molecules secreted by legume roots, and Nod factor's structure depends on species, chemical 
substitutions added which may impact legume specificity. Nitrogen fixation and legumes yields depends on the rhizobium strain, the genotype of the legume, bio-physical environment, and management practices. Rhizobium and cyanobacteria inoculants have positive feedback on plant growth and legumes yields. Inoculation of Rhizobium pisi and Pseudomonas monteilii is a promising biofertilization strategy for common bean production. The genus Agrobacterium is within the family Rhizobiaceae together with the genus Rhizobium. Agrobacterium tumefaciens, is a gram-negative, soil-born phytopathogenic bacterium which is called a nature's engineer because of its ability to genetically transform the host by transferring a DNA fragment (T-DNA) from its Ti plasmid to host-cell genome. Agrobacterium rhizogenes-mediated transformations has a lot of advantages such as fast growth rates, ease of maintenance, genetic stability, large scale biomas production which does not need external usage of phytohormones and ability to synthesize a broad array of valuable secondary metabolites. Hairy root cultures have been studied for application as pharmaceuticals, nutraceuticals, food additives and cosmetic. Hairy root caused by Agrobacterium rhizogenes and cane gall caused by $A$. rubi. Slow-growing rhizobia classified within the genus Bradyrhizobium, including $B$. japonicum, $B$. lupine, $B$. canariense and $B$. elkanii species have role in nodulating of lupines species. $B$. japonicum also recommend as a plant growth-promoting rhizobacterium for various plant species in sites contaminated with heavy metals. Herbaspirillumseropedicae which can colonize a variety of higher plants, are diazotrophic endophytes. This endophytic diazotrophic $\beta$-Proteobacterium nitrogen-fixing bacterium has association with important agricultural plants such as rice, maize, sorghum, sugarcane and wheat for nitrogen fixation. Stages of $\mathrm{H}$. seropedicae actions with crops are bacteria attachment to root surface, colonization of the emergence points in secondary roots, penetration through discontinuities of the epidemic tissue, colonization of root xylem, aerenchyma end aerial parts along with intercellular spaces occupation, and lipopolysaccharies is involved in the communication between bacteria and their hosts like the genus of Agrobacterium, Pseudomonas, and Azospirillum. Sinorhizobium meliloti is a Gram-negative soil bacterium which accumulates $N$ acetylglutaminyl glutamine amide and trehalose in hyperosmolarity and its survival needs developing active adaptive mechanisms quite different in humidity and aridity. The nifA gene of $S$. meliloti is the most important regulator which activates the expression of fix genes and a bunch of nif.

\section{Authors' Contributions}

All authors read and approved the final manuscript.

\section{Acknowledgements}

This work was supported by the National Key R\&D Program of China (Research grant 2019YFA0904700). This research was also funded by the Natural Science Foundation of Beijing, China (Grant No. M21026).

\section{Conflict of Interests}

The authors declare that there are no conflicts of interest related to this article. 


\section{References}

Abdallat AMA, Sawwan JS, Zoubi BA (2011). Agrobacterium tumefaciens-mediated transformation of callus cells of Crataegus aronia. Plant Cell Tissue and Organ Culture (PCTOC) 104:31-39. https://doi.org/10.1007/s11240010-9798-1

Abdollahi M, Soleymani A, Shahrajabian MH (2018). Evaluation of yield and some physiological indices of potato cultivars in relation to chemical, biologic and manure fertilizers. Cercetari Agronomice in Moldova 51(2):5366. https://doi.org/10.2478/cerce-2018-0016

Acosta JL, Equiarte LE, Santamaria RI, Bustos P, Vinuesa P, Martinez-Romero E, Davila G, Gonzalez V (2011). Genomic lineages of Rhizobium etli revealed by the extent of nucleotide polymorphisms and low recombination. BMC Evolutionary Biology 11:305-317. https://doi.org/10.1186/1471-2148-11-305

Ahemad M, Khan MS (2011). Effect of ebuconazole-tolerant and plant growth promoting Rhizobium isolate MRP1 on pea-Rhizobium symbiosis. Scientia Horticulturae 129:266-272. https://doi.org/10.1016/j.scienta.2011.03.036

Ahmad M, Zahir ZA, Khalid M, Nazli F, Arshad M (2013). Efficacy of Rhizobium and Pseudomonas strains to improve physiology, ionic balance and quality of mung bean under salt-affected conditions on farmer's fields. Plant Physiology and Biochemistry 63:170-176. https://doi.org/10.1016/j.plaphy.2012.11.024

Ahnia H, Bourebaba Y, Duran D, Boulila F, Palacios JM, Rey L, Ruiz-Argueso T, Boulila A, Imperial J (2018). Bradyrhizobium algeriense sp. nov., a novel species isolated from effective nodules of Retama sphaero carpa from Northeastern Algeria. Systematic and Applied Microbiology 41:333-339. https://doi.org/10.1016/j.syapm.2018.03.004

Alami S, Lamin H, Bouhnik O, El Faik S, Filali-Maltouf A, Abdelmoumen H, Bedmar EJ, El Idrissi MM (2019). Astragalus algarbiensis is nodulated by the genistearum symbiovar of Bradyrhizobium spp. in Morocco. Systematic and Applied Microbiology 42:440-447. https://doi.org/10.1016/j.syapm.2019.03.004

Alberton O, Kaschuk G, Hungria M (2006). Sampling effects on the assessment of genetic diversity of rhizobia associated with soybean and common bean. Soil Biology and Biochemistry 38:1298-1307. https://doi.org/10.1016/j.soilbio.2005.08.018

Alvarez-Martinez ER, Valverde A, Ramirez-Bahena MH, Garcia-Fraile P, Tejedor C, Mateos FP, ... Velazquez E (2009). The analysis of core and symbiotic genes of rhizobia nodulating Vicia from different continents reveals their common phylogenetic origin and suggests the distribution of Rhizobium leguminosarum strains together with Vicia seeds. Archives in Microbiology 191:659-668. https://doi.org/10.1007/s00203-009-0495-6

Amarger N (2001). Rhizobia in the field. Advances in Agronomy 73:109-168. https://doi.org/10.1016/s00652113(01)73006-4

Anyango B, Wilson KJ, Beynon JL, Giller KE (1995). Diversity of rhizobia nodulating Phaseolus vulgaris L. in two Kenyan soils with contrasting pHs. Applied and Environmental Microbiology 61:4016-4021. https://doi.org/10.1128/aem.61.11.4016-4021.1995

Arfaoui A, El Hadrami A, Mabrouk Y, Sifi B, Boudabous A, El Hadrami I, Daayf F, Cherif M (2007). Treatment of chickpea with Rhizobium isolates enhances the expression of phenylpropanoid defense-related genes in response to infection by Fusarium oxysporum f. sp. ciceris. Plant Physiology and Biochemistry 45:470-479. https://doi.org/10.1016/j.plaphy.2007.04.004

Armendariz AL, Talano MA, Nicotra MFO, Escudero L, Breser ML, Porporatto C, Agostini E (2019). Impact of double inoculation with Bradyrhizobium japonicum E109 and Azospirillum brasilense Az39 on soybean plants grown under arsenic stress. Plant Physiology and Biochemistry 138:26-35. https://doi.org/10.1016/j.plaphy.2019.02.018

Aserse AA, Rasanen LA, Assefa F, Hailemariam A, Lindstrom K (2012). Phylogeny and genetic diversity of native rhizobia nodulating common bean (Phaseolus vulgaris L.) in Ethiopia. Systematic and Applied Microbiology 35:120-131. https://doi.org/10.1016/j.syapm.2011.11.005

Babu S, Prasanna R, Bidyarani N, Nain L, Shivay YS (2015). Synergistic action of PGP agents and Rhizobium spp. for improved plant growth, nutrient mobilization and yields in different leguminous crops. Biocatalysis and Agricultural Biotechnology 4:456-464. https://doi.org/10.1016/j.bcab.2015.09.004

Bahramnejad B, Naji M, Bose R, Jha S (2019). A critical review on use of Agrobacterium rhizogenes and their associated binary vectors for plant transformation. Biotechnology Advances 37:107405. https://doi.org/10.1016/j.biotechadv.2019.06.004 
Bahroun A, Jousset A, Mhamdi R, Mrabet M, Mhadhbi H (2018). Anti-fungal activity of bacterial endophytes associated with legumes against Fusarium solani: assessment of fungi soil suppressiveness and plant protection induction. Applied Soil Ecology 124:131-140. https://doi.org/10.1016/j.apsoil.2017.10.025

Bai Y, Rottwinkel G, Feng J, Liu Y, Lamparter T (2016). Bacteriophytochromes control conjugation in Agrobacterium fabrum. Journal of Photochemistry and Photobiology B: Biology 161:192-199. https://doi.org/10.1016/j.jphotobiol.2016.05.014

Balassa R (1957). Desoxyribonucleic acid induced changes in Rhizobia. Acta Microbiologica Academiae Scientiarum Hungaricae 4:77-84.

Baldani JI, BaldaniVLD, Seldin L, Dobereiner J (1986). Characterization of Hebaspirillum seropedicae gen. nov., sp. nov., a root-associated nitrogen-fixing bacterium. International Journal of Systematics and Bacteriology 36:86-93. https://doi.org/10.1099/00207713-36-1-86

Baltrus DA, Dougherty K, Arendt KR, Huntemann M, Clum A, Pillay M, ... Arnold AE (2017). Absence of genome reduction in diverse, facultative endohyphal bacteria. Microbial Genomics 3:1-12. https://doi.org/10.1099/mgen.0.000101

Belhadi D, Lajudie PD, Ramdani N, Le Roux C, Boulila F, Tisseyre P, ... Laguerre G (2018). Vicia faba L. in the Bejaia region of Algeria is nodulated by Rhizobium leguminosarum sv. viciae, Rhizobium laguerreae and two new genospecies. Systematic and Applied Microbiology 41:122-130. https://doi.org/10.1016/j.syapm.2017.10.004

Bellini RG, Coronado MA, Paschoal AR, Rego TGD, Hungria M, Vasconcelos ATRD, Nicolas MF (2019). Structural analysis of a novel N-carbamoyl-D-amino acid amidohydrolase from a Brazilian Bradyrhizobium japonicum strain: In silico insights by molecular modeling, docking and molecular dynamics. Journal of Molecular Graphics and Modelling 86:35-42. https://doi.org/10.1016/j.jmgm.2018.10.005

Better M, Lewis B, Corbin D, Ditta G, Helinski DR (1984). Structural relationships among Rhizobium meliloti symbiotic promoters. Cell 35:479-485. https://doi.org/10.1016/0092-8674(83)90181-2

Bhattacharya I, Das HR (2003). Cell surface characteristics of two halotolerant strains of Sinorhizobium meliloti. Microbiological Research 158:187-194. https://doi.org/10.1078/0944-5013-00195

Botsford JL, Lewis TA (1990). Osmoregulation in Rhizobium meliloti: production of glutamic acid in response to osmotic stress. Applied and Environmental Microbiology 56:488-494. https://doi.org/10.1128/aem.56.2.488494.1990

Breedveld MW, ZevenhuizenLPTM, Zehnder AJB (1990). Osmotically induced oligo- and polysaccharide synthesis by Rhizobium melilotiSU-47. Microbiology 136:2511-2519. https://doi.org/10.1099/00221287-136-12-2511

Brewer TE, Stroupe ME, Jones KM (2014). The genome, proteome and phylogenetic analysis of Sinorhizobium meliloti phage $\Phi \mathrm{M12}$, the founder of a new group of T4-superfamily phages. Virology 450-451:84-97. https://doi.org/10.1016/j.virol.2013.11.027

Brilli M, Fondi M, Fani R, Mengoni A, Ferri L, Bazzicalupo Mand Biondi EG (2010). The diversity and evolution of cell cycle regulation in alpha-proteobacteria: a comparative genomic analysis. BMC Systems Biology 4:52. https://doi.org/10.1186/1752-0509-4-52

Brique A, Devassine J, Pilard S, Cailleu D, Gosselin I (2010). Osmoregulated trehalose-derived oligosaccharides in Sinorhizobium meliloti. FEBS Letters 584:3661-3666. https://doi.org/10.1016/j.febslet.2010.07.047

Bromfield ESP, Cloutier S, Tambong JT, Thi TVT (2017). Soybeans inoculated with root zone soils of Canadian native legumes harbour diverse and novel Bradyrhizobium spp. that possess agricultural potential. Systematic and Applied Microbiology 40:440-447. https://doi.org/10.1016/j.syapm.2017.10.003

Bush AL, Pueppke SG (1991). Characterization of an unusual new Agrobacterium tumedacients strain from Chrysanthemum moriflorum Ram. Applied and Environmental Microbiology 57:2468-2472. https://doi.org/10.1128/aem.57.9.2468-2472.1991

Cao Y, Wang E-T, Zhao L, Chen W-M, Wei G-H (2014). Diversity and distribution of rhizobia nodulated with Phaseolus vulgaris in two ecoregions of China. Soil Biology and Biochemistry 78:128-137. https://doi.org/10.1016/j.soilbio.2014.07.026

Cao Y, Wang E, Tong W, QiaoY, Zhao L, Chen W, Wei G (2017). Population structure of Rhizobium etli-like strains nodulated with Phaseolusvulgaris in two ecoregions of China. Soil Biology and Biochemistry 112:14-23. https://doi.org/10.1016/j.soilbio.2017.04.017

Cardoso P, Corticeiro S, Freitas R, Figueira E (2018). Different efficiencies of the same mechanisms result in distinct Cd tolerance within Rhizobium. Ecotoxicology and Environmental Safety 150:260-269. https://doi.org/10.1016/j.ecoenv.2017.12.002 
Carelli M, Gnocchi S, Fancelli A, Mengoni D, Paffetti D, Scotti C, Bazzicalupo M (2000). Genetic diversity and dynamics of Sinorhizobiummeliloti populations nodulating different alfalfa cultivars in Italian soils. Applied and Environmental Microbiology 66:4785-4789. https://doi.org/10.1128/aem.66.11.4785-4789.2000

Cassan F, Perrig D, Sgroy V, Masciarelli O, Penna C, Luna V (2009). Azospirillum brasilense Az39 and BradyrhizobiumjaponicumE109, inoculated singly or in combination, promote seed germination and early seedling growth in corn (Zea mays L.) and soybean (Glycine max L.). European Journal of Soil Biology 45:28-35. https://doi.org/10.1016/j.ejsobi.2008.08.005

Catalan AI, Ferreira F, Gill PR, Batista S (2007). Production of polyhydroxyalkanoates by Herbaspirillum seropedicae grown with different sole carbon sources and on lactose when engineered to express the lacZlacY genes. Enzyme and Microbial Technology 40:1352-1357. https://doi.org/10.1016/j.enzmictec.2006.10.008

Chahboune R, Carro L, Peix A, Barrijal A, Velazquez E, Bedmar EJ (2011). Bradyrhizobium cytisi sp. nov., isolated from effective nodules of Cytisusvillosus. International Journal of Systematic Evolution and Microbiology 61:29222927. https://doi.org/10.1099/ijs.0.027649-0

Chahboune R, Carro L, Peix A, Ramirez-Bahena MH, Barrijal S, Velazquez E, Bedmar EJ (2012). Bradyrhizobium rifense sp. nov. isolated from effective nodules of Cytisus villosus grown in the Moroccan Rif. Systematic and Applied Microbiology 35:302-305. https://doi.org/10.1016/j.syapm.2012.06.001

Chandra S, Chandra R (2011). Engineering secondary metabolite production in hairy roots. Phytochemistry Review 10:371-395. https://doi.org/10.1007/s11101-011-9210-8

Chaudhary SK, Inouhe M, Rai UN, Mishra K, Gupta DK (2011). Inoculation of Rhizobium (VR-1 and VA-1) induces an increasing growth and metal accumulation potential in Vigna radiate and Vigna angularis L. growing under flyash. Ecological Engineering 37:1254-1257. https://doi.org/10.1016/j.ecoleng.2011.03.005

Chaves DFS, de Souza EM, Monteiro RA, Pedrosa FDO (2009). A two-dimensional electrophoretic profile of the proteins secreted by Herbaspirillum seropedicae strain Z78. Journal of Proteomics 73:50-56. https://doi.org/10.1016/j.jprot.2009.07.012

Chekol T, Vough LR, Chaney RL (2004). Phytoremediation of polychlorinated biphenyl-contaminated soils: the rhizosphere effect. Environment International 30:799-804. https://doi.org/10.1016/j.envint.2004.01.008

Chen X, Stone M, Schlagnhaufer C, Romaine CP (2000). A fruiting body tissue method for efficient Agrobacteriummediated transformation of Agaricus bisporus. Applied and Environmental Microbiology 66(10):4510-4513. https://doi.org/10.1128/aem.66.10.4510-4513.2000

Chen L, Cai Y, Liu X, Guo C, Sun S, WuC, Jiang B, Han T, Hou W (2018). Soybean hairy roots produced in vitro by Agrobacterium thizogenese-mediated transformation. The Crop Journal 6:162-171. https://doi.org/10.1016/j.cj.2017.08.006

Chilton WS, Stomp AM, Beringue V, Bouzar H, Vaudequin-Dransart V, Petit A, Dessaux Y (1995). The chrysopine family of Amadori-type crown gall opines. Phytochemistry 40:619-628. https://doi.org/10.1016/00319422(93)00283-I

Christey MC, Braun RH (2005). Production of hairy roots cultures and strategic plants by Agrobacterium rhizogenesmediated transformation, in: Leandro Pena (Ed). Transgenic Plants: Methods and Protocols, Methods in Molecular Biology, Vol. 286, Humana Press, Totowa, New Jersey, USA 2005, pp 47-60. https://doi.org/10.1385/1-59259-827-7:047

Collier J (2012). Regulation of chromosomal replication in Caulobacter crescentus. Plasmid 67:76-87. https://doi.org/10.1016/j.plasmid.2011.12.007

Conn HJ (1938). Taxonomic relationships of certain non-sporeforming rods in soil. Journal of Bacteriology 36:320-321. https://doi.org/10.1128/jb.39.2.207-226.1940

Conn HJ (1942). Validity of the genus Alcaligenes. Journal of Bacteriology 44:353-360. https://doi.org/10.1128/jb.44.3.353-360.1942

Cooper JE (2007). Early interactions between legumes and rhizobia: disclosing complexity in a molecular dialogue. Journal of Applied Microbiology 103:1355-1365. https://doi.org/10.1111/j.1365-2672.2007.03366.x

Da HN, Deng SP (2003). Survival and persistence of genetically modified Sinorhizobiummeliloti in soil. Applied Soil Ecology 22:1-14. https://doi.org/10.1016/s0929-1393(02)00127-0

Dai S, Ping Z, Marmey P, Zhang S, Tian W, Chen S, Beachy RN, Fauquet C (2001). Comparative analysis of transgenic rice plants obtained by Agrobacterium-mediated transformation and particle bombardment. Molecular Breeding 7:25-33. https://doi.org/10.1023/a:1009687511633 
Dall'Agnol RF, Ribeiro RA, Ormeno-Orrillo E, Rogel MA, DelamutaJRM, Andrade DS, Martinez-Romero R, Hungria M (2013). Rhizobium freirei sp. nov., a symbiont of Phaseolus vulgaris that is very effective at fixing nitrogen. International Journal of Systematic and Evolutionary Microbiology 63:4167-4173. https://doi.org/10.1099/ijs.0.052928-0

Dang W, Wei Z-M (2007). An optimized Agrobacterium-mediated transformation for soybean for expression of binary insect resistance genes. Plant Science 173: 381-389. https://doi.org/10.1016/j.plantsci.2007.06.010

Dardanelli MS, Cordoba FJFD, Espuny MR, Carvajal MAR, Diaz MES, Serrano AM, ... Megias M (2008). Effect of Azospirillum brasilense coinoculated with Rhizobium on Phaseolus vulgaris flavonoids and Nod factor production under salt stress. Soil Biology and Biochemistry 40:2713-2721. https://doi.org/10.1016/j.soilbio.2008.06.016

Das DR, Horvath B, Kundu A, Kalo P, DasGupta M (2019). Functional conservation of CYCLOPS in crack entry legume Arachis hypogaea. Plant Science 281:232-241. https://doi.org/10.1016/j.plantsci.2018.12.003

Deepika KV, Raghuram M, KarialiE, Bramhachari PV (2016). Biological responses of symbiotic Rhizobium radiobacter strain VBCK1062 to the arsenic contaminated rhizosphere soils of mung bean. Ecotoxicology and Environmental Safety 134:1-10. https://doi.org/10.1016/j.ecoenv.2016.08.008

Degefu T, Wolde-meskel E, Woliy K, Frostegard A (2017). Phylogenetically diverse groups of Bradyrhizobium isolated from nodules of tree and annual legume species growing in Ethiopia. Systematic and Applied Microbiology 40:205-214. https://doi.org/10.1016/j.syapm.2017.04.001

De Meyer SE, van Hoorde K, Vekeman B, Braeckman T, Willems A (2011). Genetic diversity of rhizobia associated with indigenous legumes in different regions of Flanders (Belgium). Soil Biology and Biochemistry 43:2384-2396. https://doi.org/10.1016/j.soilbio.2011.08.005

De Meyer SE, De Beuf K, Vekeman B, Willems A (2015). A large diversity of non-rhizobial endophytes found in legume root nodules in Flanders (Belgium). Soil Biology and Biochemistry 83:1-11. https://doi.org/10.1016/j.soilbio.2015.01.002

Deropp RS (1951). The crown-gall problem. Botanical Reviews 17:629-670. https://doi.org/10.1007/bf02879756

Dessaux Y, Petit A, Tempe J (1993). Chemistry and biochemistry of opines, chemical mediators of parasitism. Phytochemistry 34:31-38. https://doi.org/10.1016/s0031-9422(00)90778-7

Dewir YH, El-Mahrouk ME, El-Banna AN (2015). In vitro propagation and preliminary results of Agrobacteriummediated genetic transformation of Cordyline fruticosa. South African Journal of Botany 98:45-51. https://doi.org/10.1016/j.sajb.2015.01.017

D'Haeze W, Holsters M (2002). Nod factor structures, responses and perception during initiation of nodule development. Glycobiology 12:79R-105R. https://doi.org/10.1093/glycob/12.6.79r

Dixon R, Kahn D (2004). Genetic regulation of biological nitrogen fixation. Nature Reviews Microbiology 2:621-631. https://doi.org/10.1038/nrmicro954

Dohlemann J, Brennecke M, Becker A (2010). Cloning-free genome engineering in Sinorhizobium meliloti advances applications of Cre/loxP site-specific recombination. Journal of Biotechnology 233:160-170. https://doi.org/10.1016/j.jbiotec.2016.06.033

Dos SantosCLR, Alves GC, Macedo AVDM, Giori FG, Pereira W, Urquiaga S, Reis VM (2017). Contribution of a mixed inoculants containing strains of Burkholderia spp. and Herbaspirillum ssp. to the growth of three sorghum genotypes under increased nitrogen fertilization levels. Applied Soil Ecology 113:96-106. https://doi.org/10.1016/j.apsoil.2017.02.008

Duan C, Razavi BS, Shen G, Cui Y, Ju W, Li S, Fang L (2019). Deciphering the rhizobium inoculation effect on spatial distribution of phosphatase activity in the rhizosphere of alfalfa under copper stress. Soil Biology and Biochemistry 137:107574. https://doi.org/10.1016/j.soilbio.2019.107574

Earl CD, Ronson CW, Ausubel FM (1987). Genetic and structural analysis of the Rhizobium meliloti fixA, fixB, fixC, and fix $X$ genes. Journal of Bacteriology 169:1127-1136. https://doi.org/10.1128/jb.169.3.1127-1136.1987

Egamberdieva D, Reckling M, Wirth S (2017). Biochar-based Bradyrhizobium inoculums improves growth of lupin (Lupinus angustifolius L.) under drought stress. European Journal of Soil Biology 78:38-42. https://doi.org/10.1016/j.ejsobi.2016.11.007

Erman M, Demir S, Ocak E, Tufenkci S, Oguz F, Akkopru A (2011). Effects of Rhizobium, arbuscular mycorrhiza and whey applications on some properties in chickpea (Cicer arietinum L.) under irrigated and rainfed conditions 1Yield, yield components, nodulation and AMF colonization. Field Crops Research 12:14-24. https://doi.org/10.1016/j.fcr.2011.02.002 
Fabra A, Castro S, Taurian T, Angelini J, Ibanez F, Dardanelli M, Tonelli M, Bianucci E, Valetti L (2010). Interaction among Arachis hypogaea L. (peanut) and beneficial soil microorganisms: how much is it known? Critical Reviews in Microbiology 36:179-194. https://doi.org/10.3109/10408410903584863

Falk EC, Johnson JL, BaldaniVLD, Dobereiner J, Krieg NR (1986). Deoxyribonucleic and ribonucleic acid homology studies of the genera Azospirillum and Conglomeromona. International Journal of Systematics and Bacteriology 36:80-85. https://doi.org/10.1099/00207713-36-1-80

Fall F, Le Roux C, Ba AM, Fall D, Bakhoum N, Faye MN, Kane A, Ndoye I, Diouf D (2019). The rhizosphere of the halophytic grass Sporobolus robustus Kunth hosts rhizobium genospecies that are efficient on Prosopis juliflora (Sw.) DC and Vacheliaseyal (Del.) P.J.H. Hurter seedlings. Systematic and Applied Microbiology 42:232-239. https://doi.org/10.1016/j.syapm.2018.10.006

Fei C, Wang T, Woldemicael A, He M, Zou S, Wang C (2019). Nitrogen supplemented by symbiotic Rhizobium stimulates fatty-acid oxidation in Chlorella variabilis. Algal Research 44:101692. https://doi.org/10.1016/j.algal.2019.101692

Feng J, Li FQ, Li Q, Hu HL, Hong GF (2002). Expression and purification of Rhizobium leguminosarum NodD. Protein Expression and Purification 26:321-328. https://doi.org/10.1016/s1046-5928(02)00535-1

Ferri L, GoriA, Biondi EG, Mengoni A, Bazzicalupo M (2010). Plasmid electroporation of Sinorhizobium strains: The role of the restriction gene $h s d R$ in type Rm1021. Plasmid 63:128-135. https://doi.org/10.1016/j.plasmid.2010.01.001

Ferro L, Gojkovic Z, Munoz R, Funk C (2019). Growth performance and nutrient removal of a Chlorella vulgarisRhizobium sp. co-culture during mixotrophic feed-batch cultivation in synthetic wastewater. Algal Research 44:101690. https://doi.org/10.1016/j.algal.2019.101690

Ferroni FM, Guerrero SA, Rizzi AC, Brondino CD (2012). Overexpression, purification, and biochemical and spectroscopic characterization of copper-containing nitrite reductase from Sinorhizobium meliloti. Study of the interaction of the catalytic copper center with nitrite and NO. Journal of Inorganic Biochemistry 114:8-14. https://doi.org/10.1016/j.jinorgbio.2012.04.016

Finan TM, Hartweig E, LeMieuz K, Bergman K, Walker GC, Signer ER (1984). General transduction in Rhizobium meliloti. Journal of Bacteriology 159:120-124. https://doi.org/10.1128/jb.159.1.120-124.1984

Flores-Felix JD, Velazquez E, Garcia-Fraile P, Gonzalez-Andres F, Silva LR, Rivas R (2018). Rhizobium and Phyllobacterium bacterial inoculants increase bioactive compounds and quality of strawberries cultivated in field conditions. Food Research International 111:416-422. https://doi.org/10.1016/j.foodres.2018.05.059

Flores-Felix JD, Sanchez-Juanes F, Garcia-Fraile P, Valverde A, Mateos PF, Gonzalez-Buitrago JMG, ... Rivas R (2019). Phaseolus vulgaris is nodulated by the symbiovarviciae of several genospecies of Rhizobium laguerreae complex in a Spanish region where Lens culinaris is the traditionally cultivated legume. Systematic and Applied Microbiology 42:240-247. https://doi.org/10.1016/j.syapm.2018.10.009

Flores-Felix JD, Menendez E, Peix A, Garcia-Fraile P, Velazquez E (2020). History and current taxonomic status of genus $\begin{array}{lllll}\text { Agrobacterium. } & \text { Systematic applied } & \text { Microbiology } & \text { 43:126046. }\end{array}$ https://doi.org/10.1016/j.syapm.2019.126046

Frank B (1889). Uber die Pilzsymbiose der Leguminosen. Berichte der Deutschen Botanischen Gesellschaft. 7: $332-346$ (in German).https://doi.org/10.1002/cber.188902202265

Gabor M (1965). Transformation of streptomycin markers in rough strains of Rhizobium lupini II. The relation between the determinant of streptomycin dependence and those for streptomycin resistance and sensitiveness. Genetics 52 : 05-913. https://doi.org/10.1093/genetics/52.5.905

Gage DJ (2004). Infection and invasion of roots by symbiotic, nitrogen-fixing rhizobia during nodulation of temperate legumes. Microbiology and Molecular Biology Research 68:280-300. https://doi.org/10.1128/mmbr.68.2.280300.2004

Galibert F (2001). The composite genome of the legume symbiont Sinorhizobium meliloti. Science 293:668-672. https://doi.org/10.1126/science.1060966

Galvao CW, Pedrosa FO, Souza EM, Yates MG, Chubatsu LS, Steffens MBR (2004). Expression, purification, and DNAbinding activity of the Herbaspirillum seropedicae RecX protein. Protein Expression and Purification 35:298-303. https://doi.org/10.1016/j.pep.2004.01.014

Gao C, Long D, Lenk I, Nielsen KK (2008). Comparative analysis of transgenic tall fescue (Festuca arundinaceae Schreb.) plant obtained by Agrobacterium-mediated transformation and particle bombardment. Plant Cell Reports 27:1601-1609. https://doi.org/10.1007/s00299-008-0578-X 
Gao Y, Duan A, Qiu X, Liu Z, Sun J, Zhang J, Wang H (2010). Distribution of roots and root length density in a maize/soybean strip intercropping system. Agricultural Water Management 98(1):199-212. https://doi.org/10.1016/j.agwat.2010.08.021

Gao F-L, Che X-X, Yu F-H, Li J-M (2019). Cascading effects of nitrogen, rhizobia and parasitism via a host plant. Flora 251:62-67. https://doi.org/10.1016/j.flora.2018.12.007

Garcia-Fraile P, Mulas-Garcia D, Peix A, Rivas R, Gonzalez-Andres F, Velazquez E (2010). Phaseolus vulgaris is nodulated in northern Spain by Rhizobium leguminosarum strains harboring two nodC alleles present in American Rhizobium etlistrains: biogeographical and evolutionary implications. Canadian Journal of Microbiology 56:657666. https://doi.org/10.1139/w10-048

Garcia JE, Maroniche G, Creus C, Suarez-Rodriguez R, Ramirez-Trujillo JA, Groppa MD (2017). In vitro PGPR properties and osmotic tolerance of different Azospirillum native strains and their effects on growth of maize under drought stress. Microbiology Research 202:21-29. https://doi.org/10.1016/j.micres.2017.04.007

Geurts R, Bisseling T (2002). Rhizobium nod factor perception and signaling. Plant Cell 14:S239-S249. https://doi.org/10.1105/tpc.002451

Gibson KE, Kobayashi H, Walker GC (2008). Molecular determinants of a symbiotic chronic infection. Annual Reviews in Genetics 42:413-441. https://doi.org/10.1146/annurev.genet.42.110807.091427

GillerKE, FrankeAC, Abaidoo R, Baijukya F, Bala A, Boahen S, ... Vanlauwe B (2013). N2Africa: putting nitrogen fixation to work for smallholder farmers in Africa. In: Vanlauwe B, van AstenPJA, Blomme G (Eds). Agroecological Intensification of Agricultural Systems in the African Highlands, Routledge, London, pp 156-174. https://doi.org/10.4324/9780203114742-24

Ghosh PK, SahaP, Mayilraj S, Maiti TK (2013). Role of IAA metabolizing enzymes on production of IAA in root, nodule of Cajanus cajan and its PGP Rhizobium sp. Biocatalysis and Agricultural Biotechnology 2:234-239. https://doi.org/10.1016/j.bcab.2013.04.002

Ghosh PK, Maiti TK (2016). Structure of extracellular polysaccharides (EPS) produced by rhizobia and their functions in legume-bacteria symbiosis: - A review. Achievements in the Life Sciences 10:136-143. https://doi.org/10.1016/j.als.2016.11.003

Gong Z, Zhu J, Yu G, Zou H (2007). Disruption of nifA gene influences multiple cellular processes in Sinorhizobiummeliloti. Journal of Genetics and Genomics 34(9):783-789. https://doi.org/10.1016/s16738527(07)60089-7

Gonzalez LE, Bashan Y (2000). Increased growth of the microalga Chlorella vulgaris when coimmobilized and cocultured in alginate beads with the plant-growth-promoting bacterium Azospirillumbrasilense. Applied and Environmental Microbiology 66:1527-1531. https://doi.org/10.1128/aem.66.4.1527-1531.2000

Goodner B, Hinkle G, Gattung S, Miller N, Blanchard M, Qurollo B, ... Slater S (2001). Genome sequence of the plant pathogen and biotechnology agent Agrobacterium tumefaciens C58. Science 294:2323-2328. https://doi.org/10.1126/science.1066803

Gosselin I, Wattraint O, Riboul D, Barbotin J-N, Portais J-C (2001). A deeper investigation on carbohydrate cycling in Sinorhizobiummeliloti. FEBS Letters 499:45-49. https://doi.org/10.1016/s0014-5793(01)02518-2

Govarthanan M, Lee G-W, Park J-H, Kim JS, Lim S-S, Seo S-K, Cho M, Myung H, Kamala-Kannan S, Oh B-T (2014). Bioleaching characteristics, influencing factors of $\mathrm{Cu}$ solubilization and survival of Herbaspirillum sp. GW 103 in Cu contaminated mine soil. Chemosphere 109:42-48. https://doi.org/10.1016/j.chemosphere.2014.02.054

Grange L, Hungria M (2004). Genetic diversity of indigenous common bean (Phaseolus vulgaris) rhizobia in two Brazilian ecosystems. Soil Biology and Biochemistry 36:1389-1398. https://doi.org/10.1016/j.soilbio.2004.03.005

Gresta F, Trostle C, Sortino O, Santonoceto C, Avola G (2019). Rhizobium inoculation and phosphate fertilization effects on productive and qualitative traits of guar (Cyamopsis tetragonoloba (L.) Taub.). Industrial Crops and Products 139:111513. https://doi.org/10.1016/j.indcrop.2019.111513

Gu S-B, Yao J-M, Yuan Q-P, Xue P-J, Zheng Z-M, Yu Z-L (2006). Kinetics of Agrobacterium tumefaciens ubiquinone10 batch production. Process Biochemistry 41:1908-1912. https://doi.org/10.1016/j.procbio.2006.04.002

Guo M, Gao D, Jin Y (2009). Progress in the formation and transfer of Agrobacterium T-complex. Progress in Biochemistry and Biophysics 36:1408-1414. https://doi.org/10.3724/sp.j.1206.2009.00195

Guo M, Bian X, Wu X, Wu M (2011). Agrobacterium-mediated genetic transformation: history and progress. In: Alvarez M (Ed). Genetic Transformation. InTech, Rijeka, pp 3-28. https://doi.org/10.5772/22026 
Guo M, Huang Z, Yang J (2017). Is there any crosstalk between the chemotaxis and virulence induction signaling in Agrobacterium tumefaciens? Biotechnology 35:505-511. https://doi.org/10.1016/j.biotechadv.2017.03.008

Guo Y, Matsuoka Y, Miura T, Nishizawa T, Ohta H, Narisawa K (2018). Complete genome sequence of Agrobacterium pusense VsBac-Y9, a bacterial symbiont of the dark septate endophytic fungus Veronaeopsis simplexY34 with potential for improving fungal colonization in roots. Journal of Biotechnology 284:31-36. https://doi.org/10.1016/j.jbiotec.2018.07.045

Guo M, Ye J, Gao D, Xu N, Yang J (2019). Agrobacterium-mediated horizontal gene transfer: Mechanism, biotechnological application, potential risk and forestalling strategy. Biotechnology Advances 37:259-270. https://doi.org/10.1016/j.biotechadv.2018.12.008

Haag AF, Arnold MFF, Myka KK, Kerscher B, Dallangelo S, Zanda M, Mergaret P, Ferguson GP (2013). Molecular insights into bacteroid development during Rhizobium-legume symbiosis. FEMS Microbiology Reviews 37:364383. https://doi.org/10.1111/1574-6976.12003

Han SZ, Wang ET, Chen WX (2005). Diverse bacteria isolated from root nodules of Phaseolus vulgaris and species within the genera Campylotropis and Cassia growtn in China. Systematic and Applied Microbiology 28:265-276. https://doi.org/10.1016/j.syapm.2004.12.005

Han TX, Wang ET, Han LL, Chen WF, Sui XH, Chen WX (2008). Molecular diversity and phylogeny of rhizobia associated with wild legumes native to Xinjiang, China. Systematic and Applied Microbiology 31:287-301. https://doi.org/10.1016/j.syapm.2008.04.004

Hanana M, Ayadi R, Mzid R, Khouja ML, Hanachi AS, Hamrouni L (2018). Efficient method of seed transformation via Agrobacterium tumefaciens for obtaining transgenic plants Hibiscus cannabinus L. Industrial Crops and Products 113:274-282. https://doi.org/10.1016/j.indcrop.2018.01.050

He R, Pan J, Zhu L, He G (2010). Agrobacterium-mediated transformation of large DNA fragments using a BIBAC vector system in rice. Plant Molecular Biology Reporter 28:613-619. https://doi.org/10.1007/s11105-010-0195$z$

Hidaka T, Omura M (1993). Transformation of citrus protoplasts by electroporation. Journal of Japan Society of Horticulture Sciences 62:371-376. https://doi.org/10.2503/jjshs.62.371

Hu J, Zhou Y, Lei Z, Liu G, Hua Y, Zhou W, Wan X, Zhu D, Zhao J (2020). Effects of Potamogeton crispus decline in the rhizosphere on the abundance of anammox bacteria and nir $S$ denitrifying bacteria. Environmental Pollution 260:114018. https://doi.org/10.1016/j.envpol.2020.114018

Huang P, Xu M, Xia L, Qing Z, Tang Q, Liu W, Zeng J (2017). Establishment of an efficient Agrobacterium-mediated genetic transformation method in Macleayacordata. Scientia Horticulturae 226:302-306. https://doi.org/10.1016/j.scienta.2017.09.004

Hungria M, Andrade DS, Chueire LMO, Probanza A, Guttierrez-Manero FJ, Megias M (2000). Isolation and characterization of new efficient and competitive bean (Phaseolus vulgaris L.) rhizobia from Brazil. Soil Biology and Biochemistry 32(11):1515-1528. https://doi.org/10.1016/s0038-0717(00)00063-8

Huser A, Takahara H, Schmalenbach W, O'Connell R (2009). Discovery of pathogenicity genes in the crucifer anthracnose fungus Colletotrichum higginsianum, using random insertional mutagenesis. Molecular Plant Microbe Interactions 22:143-156. https://doi.org/10.1094/mpmi-22-2-0143

Ide Franzini V, Azcon R, Mendes FL, Aroca R (2010). Interaction between Glomus species and Rhizobium strains affect the nutritional physiology of drought-stressed legume hosts. Journal of Plant Physiology 167:614-619. https://doi.org/10.1016/j.jplph.2009.11.010

Idnurm A, Bailey AM, Cairns TC, Elliott CE, Foster GD, Laniri G, Jeon J (2017). A silver bullet in a golden age of functional genomics: the impact of Agrobacterium-mediated transformation of fungi. Fungal Biology and Biotechnology 4:6. https://doi.org/10.1186/s40694-017-0035-0

Islam MN, Nizam S, Verma PK (2012). A highly efficient Agrobacterium mediated transformation system for chickpea wilt pathogen Fusarium oxysporum f. sp. ciceri using DsRed-Express to follow root colonization. Microbiology Research 167:32-338. https://doi.org/10.1016/j.micres.2012.02.001

Jack CN, Wozniak KJ, Porter SS, Friesen ML (2019). Rhizobia protect their legume hosts against soil-borne microbial antagonists in a hose-genotype-dependent manner. Rhizosphere 9:47-55. https://doi.org/10.1016/j.rhisph.2018.11.005 
Janczarek M, Rachwal K, Marzec A, Grzadziel J, Palusinska-Szysz M (2015). Signal molecules and cell-surface components involved in early stages of the legume-rhizobium interactions. Applied Soil Ecology 85:94-113. https://doi.org/10.1016/j.apsoil.2014.08.010

Jeon J, Park SY, Chi MH, Choi J, ParkJ, Rho HS, ... Lee YH (2007). Genome-wide functional analysis of pathogenicity genes in the rice blast fungus. Nature Genetics 39:561-565. https://doi.org/10.1038/ng2002

Ji Z, Liu T, Zhang J, Yan H, WangE, Cui Q, Chen Q, Chen W (2019). Genetic divergence among Bradyrhizobium strains nodulating wild and cultivated Kummerowia spp. in China. Systematic and Applied Microbiology 42:223-231. https://doi.org/10.1016/j.syapm.2018.10.003

Jiang DW, Zhu W, Wang YC, Sun C, Zhang KQ, Yang JK (2013). Molecular tools for functional genomics in filamentous fungi: recent advances and new strategies. Biotechnology Advances 31:1562-1574. https://doi.org/10.1016/j.biotechadv.2013.08.005

Jones KM, Kobayashi H, Davies BW, Taga ME, Walker GC (2007). How rhizobial symbionts invade plants: the Sinorhizobium-Medicago model. Nature Reviews Microbiology 5:619-633. https://doi.org/10.1038/nrmicro1705

Jones KM, Walker GC (2008). Responses of the model legume Medicago truncatula to the rhizobial exopolysaccharide succinoglycan. Plant Signalling andBehavior 3:888-890. https://doi.org/10.4161/psb.3.10.6512

Jones RW (2016). Application of succulent plant leaves for Agrobacterium infiltration-mediated protein production. Journal of Microbiological Methods 120:65-67. https://doi.org/10.1016/j.mimet.2015.11.017

Jordan DC (1982). Transfer of Rhizobium japonicum Buchanan 1980 to Bradyrhizobium gen nov., a genus of slowgrowing, root nodule bacteria from leguminous plants. International Journal of Systematics and Bacteriology 32:136-139. https://doi.org/10.1099/00207713-32-1-136

Ju W, Liu L, Fang L, Cui Y, Duan C, Wu H (2019). Impact of co-inoculation with plant-growth-promoting rhizobacteria and rhizobium on the biochemical responses of alfalfa-soil system in copper contaminated soil. Ecotoxicology and Environmental Safety 167:218-226. https://doi.org/10.1016/j.ecoenv.2018.10.016

Junier P, Alfaro M, Guevara R, Witzel K-P, Caru M (2014). Genetic diversity of Rhizobium present in nodules of Phaseolus vulgaris L. cultivated in two soils of the central region in Chile. Applied Soil Ecology 80:60-66. https://doi.org/10.1016/j.apsoil.2014.03.014

Kaneko T (2000). Complete genome structure of the nitrogen fixing symbiotic bacterium Mesorhizobium loti. DNA Research 7:331-338. https://doi.org/10.1093/dnares/7.6.331

Kaneko T (2002). Complete genomic sequence of nitrogen-fixing symbiotic bacterium Bradyrhizobium japonicum USDA110. DNA Research 9:189-197. https://doi.org/10.1093/dnares/9.6.189

Karoney EM, Ochieno DMW, Baraza DL, Muge EK, Nyaboga EN, Naluyange V (2020). Rhizobium improves nutritive suitability and tolerance of Phaseolus vulgaris to Colletotrichum lindemuthianum by boosting organic nitrogen content. Applied Soil Ecology 149:103534. https://doi.org/10.1016/j.apsoil.2020.103534

Kastell A, Zrenner R, Schreiner M, Kroh L, Ulrichs C, Smetanska I, Mewis I (2015). Metabolic engineering of aliphatic glucosinolates in hairy root cultures of Arabidopsis thaliana. Plant Molecular Biology Reporter 33:598-608. https://doi.org/10.1007/s11105-014-0781-6

Kavitake D, Delattre C, Devi PB, Pierre G, Michaud P, Shetty PH, Andhare P (2019). Physical and functional characterization of succinoglycanexoplysaccharide produced by Rhizobium radiobacter CAS from curd sample. International Journal of Biological Macromolecules 134:1013-1021. https://doi.org/10.1016/j.ijbiomac.2019.05.050

Keller J, Imperial J, Ruiz-Argueso T, Privet K, Lima O, Michon-Coudouel S, ... Cabello-Hurtado F (2018). RNA sequencing and analysis of three Lupinus nodulomes provide new insights into specific host-symbiont relationships with compatible and incompatible Bradyrhizobium strains. Plant Science 266:102-116. https://doi.org/10.1016/j.plantsci.2017.10.015

Kereszt A, Mergaert P, Kondorosi E (2011). Bacteroid development in legume nodules: evolution of mutual benefit or of sacrificial victims? MolecularPlant-Microbe Interactions 24:1300-1309. https://doi.org/10.1094/mpmi-06-110152

Keyser HH, Munns DN (1979). Tolerance of rhizobia to acidity, aluminium, and phosphate. Soil Science Society of America Journal 43(3):519-523. https://doi.org/10.2136/sssaj1979.03615995004300030018x

Khoshkharam M, Rezaei A, Soleymani A, Shahrajabian MH (2010). Effects of tillage and residue management on yield components and yield of maize in second cropping after barley. Research on Crops 11(3):659-666. 
Kim B-H, Ramanan R, Cho D-H, Oh H-M, Kim H-S (2014). Role of Rhizobium, a plant growth promoting bacterium, in enhancing algal biomass through mutualistic interaction. Biomass and Bioenergy 69:95-105. https://doi.org/10.1016/j.biombioe.2014.07.015

Kim JW, Lee J, Yoo AY, Choi JW, Park YI, Park JK (2017). Immune-stimulating activity of water-soluble extracellular polysaccharide isolated from Rhizobium massiliae. Process Biochemistry 63:236-243. https://doi.org/10.1016/j.procbio.2017.09.005

Kinkle BK, Angle JS, Keyser HH (1987). Long-term effects of metal-rich swage sludge application on soil populations of Bradyrhizobium japonicum. Applied and Environmental Microbiology 53(2):315-319. https://doi.org/10.1128/aem.53.2.315-319.1987

Klee H, Horsch R, Rogers S (1987). Agrobacterium-mediated plant transformation and its further applications to plant biology. Annual Reviews in Plant Physiology 38:467-486. https://doi.org/10.1146/annurev.pp.38.060187.002343

Kobayashi S, Uchimiya H (1989). Expression and integration of a foreign gene in orange (Citrus sinensis Osb.) protoplasts by direct DNA transfer. Idengaku Zasshi 64:91-97. https://doi.org/10.1266/jjg.64.91

Koetle MJ, Finnie JF, Balazs E, Van Staden J (2015). A review on factors affecting the Agrobacterium-mediated genetic transformation in ornamental monocotyledonous geophytes. South African Journal of Botany 98:37-44. https://doi.org/10.1016/j.sajb.2015.02.001

Kuykendall LD, Saxena B, Devine TE, Udell SE (1992). Genetic diversity in Bradyrhizobium japonicum Jordan 1982 and a proposal for Bradyrhizobiumelkanii sp. nov. Canadian Journal of Microbiology 38:501-505. https://doi.org/10.1139/m92-082

Leclerque A, Wan H, Abschutz A, Chen S, MitinaGV, Zimmermann G, Schairer HU (2004). Agrobacterium-mediated insertional mutagenesis (AIM) of the entomopathogenic fungus Beauveria bassiana. Current Genetics 45:111119. https://doi.org/10.1007/s00294-003-0468-2

Laguerre G, Mazurier SI, Amarger N (1992). Plasmid profiles and restriction fragment length polymorphism of Rhizobium leguminosarum bv. viciae in field populations. FEMS Microbiology Letters 101(1):17-26. https://doi.org/10.1111/j.1574-6941.1992.tb01644.x

Leon-Barrios M, Perez-Yepez J, Dorta P, Garrido A, Jimenez C (2017). Alkalinity of Lanzarote soils is a factor shaping rhizobial populations with Sinorhizobium meliloti being the predominant microsymbiont of Lotus lancerottensis. Systematic and Applied Microbiology 40:171-178.

LiY, Wang ET, Liu Y, Li X, Yu B, Ren C, Liu W, Li Y, Xie Z (2016). Rhizobium anhuiense as the predominant microsymbionts of Lathyrus maritimus along the Shandong Peninsula seashore line. Systematic and Applied Microbiology 39:384-390. https://doi.org/10.1016/j.syapm.2016.07.001

Li X, Jiang Z, Shen Y, Li F, Yu X, Qu S (2018). In vitro regeneration and Agrobacterium tumefaciens-mediated genetic transformation of D. lotus (Diospyroslotus L.). Scientia Horticulturae 236:229-237. https://doi.org/10.1016/j.scienta.2018.03.054

Li YH, Wang R, Sui XH, Wang ET, Zhang XX, Tian CF, Chen WF, Chen WX (2019). Bradyrhizobium nanningense sp. nov., Bradyrhizobium guangzhouense sp. nov. and Bradyrhizobium zhanjiangense sp. nov., isolated from effective nodules of peanut in Southeast China. Systematic and Applied Microbiology 42:126002. https://doi.org/10.1016/j.syapm.2019.126002

Li J, Hong N, Peng B, Wu H, Gu Q (2019). Transformation of Corynespora cassiicola by Agrobacterium tumefaciens. Fungal Biology 123:669-675. https://doi.org/10.1016/j.funbio.2019.05.011

Lindstrom K, Mousavi SA (2010). Rhizobium and other N-fixing symbioses. In: Encyclopedia of life science (ELS). John Wiley \& Sons, Ltd., Chichester. https://doi.org/10.1002/9780470015902.a0021157

Lindstrom K, Aserse AA, Mousavi SA (2013). Taxonomy and evolution of nitrogen-fixing organisms. In: de Bruijn FJ (Ed). Biological Nitrogen Fixation. John Wiley \& Sons, Inc. https://doi.org/10.1002/9781119053095.ch3

Liu L, He Z, Wang K, Xie Y, Xie Q, O'Donnell AG, Chen C (2015). The Bradyrhizobium-legume symbiosis is dominant in the shrubby ecosystem of the Karst region, Southwest China. European Journal of Soil Biology 68:1-8. https://doi.org/10.1016/j.ejsobi.2015.02.004

Liu C-W, Murray JD (2016). The role of flavonoids in nodulation host-range specificity: an update. Plants Basel Switz. 5. https://doi.org/10.3390/plants5030033

Liu YH, Wang ET, Jiao YS, Tian CF, Wang L, Wang ZJ, ... Chen WF (2018). Symbiotic characteristics of Bradyrhizobium diazoefficiens USDA 110 mutants associated with shrubby sophora (Sophora flavescens) and soybean (Glycine max). Microbiological Research 214:19-27. https://doi.org/10.1016/j.micres.2018.05.012 
Long SR (1989). Rhizobium-legume nodulation: life together in the underfound. Cell 56:203-214. https://doi.org/10.1016/0092-8674(89)90893-3

Long L, LinQ, Shi Y, Wang J, Ding S (2018). Highly efficient transformation of a (hemi-)cellulases-producting fungus Eupenicillium parvum 4-14 by Agrobacterium tumefaciens. Journal of Microbiological Methods 146:40-45. https://doi.org/10.1016/j.mimet.2018.01.013

Lopez-Lopez A, Rogel-Hernandez MA, Barois I, Ceballos AIO, Martinez J, Ormeno-Orrillo E, Martinez-Romero E. (2012). Rhizobium grahamiisp. nov., from nodules of Dalea leporine, Leucaena leucocephala and Clitoriaternatea, and Rhizobium mesoamericanum sp. nov., from nodules of Phaseolus vulgaris, siratro, cowpea and Mimosa pudica. International Journal of Systematic and Evolutionary Microbiology 62:2264-2271. https://doi.org/10.1099/ijs.0.033555-0

Lubambo AF, Benelli EM, Klein JJ, Schreiner WH, Silveira E, de Camargo PC (2013). Tuning protein GlnB-Hs surface interaction with silicon: FTIR-ATR, AFM and XPS study. Colloids and Surfaces B: Biointerfaces 102:348-353. https://doi.org/10.1016/j.colsurfb.2012.08.006

Majumdar S, Garaj S, Jha S. (2011). Genetic transformation of Bacopamonnieri by wild type strains of Agrobacterium rhizogenes stimulates production of bacopa saponins in transformed calli and plants. Plant Cell Reports 30:941954. https://doi.org/10.1007/s00299-011-1035-9

Marek-Kozaczuk M, Leszcz A, Wielbo J, Wdowiak-Wrobel S, Skorupska A (2013). Rhizobium pisi sv. trifolii K3.22 harboring nod genes of the Rhizobium leguminosarumsv. trifolii cluster. Systematic and Applied Microbiology 36:252-258. https://doi.org/10.1016/j.syapm.2013.01.005

Martinez-Romero E, Segovia L, Mercante FM, Franco AA, Graham P, Pardo MA (1991). Rhizobium tropici, a novel species nodulating Phaseolus vulgaris L. beans and Leucaena sp. trees. International Journal of Systematic Bacteriology 41:417-426. https://doi.org/10.1099/00207713-41-3-417

Matos D, Sa C, Cardoso P, Pires A, Rocha SM, Figueira E (2019). The role of volatiles in Rhizobium tolerance to cadmium: effects of aldehydes and alcohols on growth and biochemical endpoints. Ecotoxicology and Environmental Safety 186:109759. https://doi.org/10.1016/j.ecoenv.2019.109759

Mehmannavaz R, Prasher SO, Ahmad D (2002). Rhizospheric effects of alfalfa on biotransformation of polychlorinated biphenyls in a contaminated soil augmented with Siorhizobium meliloti. Process Biochemistry 37:955-963. https://doi.org/10.1016/s0032-9592(01)00305-3

Mellal H, Yacine B, Boukaous L, Khouni S, Benguedouar A, Castellano-Hinojosa A, Bedmar EJ (2019). Phylogenetic diversity of Bradyrhizobium strains isolated from root nodules of Lupinus angustifolius grown wild in the North East of Algeria. Systematic and Applied Microbiology 42:397-402. https://doi.org/10.1016/j.syapm.2019.01.003

Michielse CB, Hooykaas PJ, Van Den Hondel CA, Ram AF (2008). Agrobacterium-mediated transformation of the filamentous fungus Aspergillus awamori. Nature Protocols 3:1671-1678. https://doi.org/10.1038/nprot.2008.154

Michielse CB, van Wijk R, Reijnen L, Cornelissen BJ, Rep M (2009). Insight into the molecular requirements for pathogenicity of Fusarium oxysporum f. sp. lycopersici through large-scale insertional mutagenesis. Genome Biology10:R4. https://doi.org/10.1186/gb-2009-10-1-r4

Miller KJ, Wood JM (1996). Osmoadaptation by rhizosphere bacteria. Annual Reviews in Microbiology 50:101-136. https://doi.org/10.1146/annurev.micro.50.1.101

Mnasri B, Saidi S, Chihaoui SA, Mhamdi R (2012). Sinorhizobium Americanum symbiovar mediterranense is a predominant symbiont that nodulates and fixes nitrogen with common bean (Phaseolus vulgaris $\mathrm{L}$.) in a Northern Tunisian field. Systematic and Applied Microbiology 35:263-269. https://doi.org/10.1016/j.syapm.2012.04.003

Mnasri B, Liu TY, Saidi S, Chen WF, Chen WX, Zhang XX, Mhamdi R (2014). Rhizobium azibense sp. nov., a nitrogen fixing bacterium isolated from root-nodules of Phaseolus vulgaris. International Journal of Systematic and Evolutionary Microbiology 058651-058650. https://doi.org/10.1099/ijs.0.058651-0

Moawad H, Beck DP (1991). Some characteristics of Rhizobium leguminosarum isolates from uninoculated field-grown lentil. Soil Biology and Biochemistry 23(10):933-937. https://doi.org/10.1016/0038-0717(91)90173-h

Monteiro RA, Souza EM, Yates MG, Pedrosa FO, Chubatsu LS (1999). In-trans regulation of the N-truncated-NIFA protein of Herbaspirillum seropedicae by the N-terminal domain. FEMS Microbiology Letters 180:157-161. https://doi.org/10.1111/j.1574-6968.1999.tb08790.x 
Monteiro RA, de Souza EM, Wassem R, Geoffrey Yates M, Pedrosa FO, Chubatsu LS (2001). Inter-domain cross-talk control the NifA protein activity of Herbaspirillum seropedicae. FEBS Letters 508:1-4. https://doi.org/10.1016/s0014-5793(01)03017-4

Monteiro RA, Souza EM, Yates MG, Steffens MBR, Pedrosa FO, Chubatsu LS (2003). Expression, purification, and functional analysis of the C-terminal domain of HerbaspirillumseropedicaeNifA protein. Protein Expression and Purification 27:313-318. https://doi.org/10.1016/s1046-5928(02)00635-6

Moon YS, Donzelli BG, Krasnoff SB, McLane H, Griggs MH, Cooke P, ... Churchill AC (2008). Agrobacteriummediated disruption of a nonribosomal peptide synthetase gene in the invertebrate pathogen Metarhizium anisopliae reveals a peptide spore factor. Applied and Environmental Microbiology 74(14):4366-4380. https://doi.org/10.1128/aem.00285-08

Moorman TB (1986). Effects of herbicides on the survival of Rhizobium japonicum strains. Weed Science 34(4):628633. https://doi.org/10.1017/s0043174500067564

Moraes NDJ, Neto VPDC, Araujo ASFD, Figueiredo MDVB, Bonifacio A, Rodriguez AC (2016). Bradyrhizobium sp. inoculation ameliorates oxidative protection in cowpea subjected to long-term composted tannery sludge amendment. European Journal of Soil Biology 76:35-45. https://doi.org/10.1016/j.ejsobi.2016.07.006

Moulin L, Bena G, Boivin-Masson C, Stepkowski T (2004). Phylogenetic analyses of symbiotic nodulation genes support vertical and lateral gene co-transfer within the Bradyrhizobium genus. Molecular Phylogenetics and Evolution 30:720-732. https://doi.org/10.1016/s1055-7903(03)00255-0

Mousavi SA, Osterman J, Wahlberg N, Nesme X, Lavire C, Vial L, ... Lindstrom K (2014). Phylogeny of the RhizobiumAllorhizobium-Agrobacterium clade supports the delineation of Neorhizobium gen. nov. Systematic and Applied Microbiology 37:208-215. https://doi.org/10.1016/j.syapm.2013.12.007

Mullins ED, Kang S (2001). Transformation: a tool for studying fungal pathogens plants. Cellular and Molecular Life Sciences 58:2043-2052. https://doi.org/10.1007/pl00000835

Mullins ED, Chen X, Romaine P, Raina R, Geiser DM, Kang S (2001). Agrobacterium-mediated transformation of Fusarium oxysporum: an efficient tool for inserional mutagenesis and gene transfer. Phytopathology 91(2):173180. https://doi.org/10.1094/phyto.2001.91.2.173

Murugan A, Prathiviraj R, Mothay D, Chellapandi P (2019). Substrate-imprinted docking of Agrobacterium tumefaciens urinate dehydrogenase for increased substrate selectivity. International Journal of Biological Macromolecules 140:1214-1225. https://doi.org/10.1016/j.ijbiomac.2019.08.194

Mwenda GM, O’Hara GW, De Meyer SE, Howieson JG, Terpolilli JJ (2018). Genetic diversity and symbiotic effectiveness of Phaseolus vulgaris-nodulating rhizobia in Kenya. Systematic and Applied Microbiology 41:291299. https://doi.org/10.1016/j.syapm.2018.02.001

Nabeshima T, Doi M, Hosokawa M (2016). Agrobacterium-mediated inoculation of chrysanthemum (Chrysanthemum morifolium) plants with chrysanthemum stunt viroid. Journal of Virological Methods 234:169-173. https://doi.org/10.1016/j.jviromet.2016.05.001

Nandasena KG, O’Hara GW, Tiwari RP, Yates RJ, Kishinevsky BD, Howieson JG (2004). Symbiotic relationships and root nodule ultrastructure of the pasture legume Biserrula pelecinus L.- a new legume in agriculture. Soil Biology and Biochemistry 36:1309-1317. https://doi.org/10.1016/j.soilbio.2004.04.012

Nathoo N, MacDonald J, Weselowski B, Yuan Z-C (2019). Comparative transcriptomic analysis reveals different responses of Arabidopsis thaliana roots and shoots to infection by Agrobacterium tumefaciens in a hydroponic cocultivation system. Physiological and Molecular Plant Pathology 106:109-119. https://doi.org/10.1016/j.pmpp.2019.01.001

Nester EW (2015). Agrobacterium: nature's genetic engineer. Frontiers in Plant Science 5:730. https://doi.org/10.3389/fpls.2014.00730

Niazian M, Sadat-Noori SA, Tohidfar M, Galuscka P, Mortazavian SMM (2019). Agrobacterium-mediated genetic transformation of ajowan (Trachys permumammi (L.) Sprague): an important industrial medicinal plant. Industrial Crops and Products 132:29-40. https://doi.org/10.1016/j.indcrop.2019.02.005

Nick G, de Lajudie P, Eardly BD, Suomalainen S, Paulin L, Zhang XP, Gillis M, Lindstrom K (1999). Sinorhizobium arboris sp. nov. and Sinorhzobium kostiense sp. nov., isolated from leguminous tress in Sudan and Kenay. International Journal of Systematic and Evolutionary Microbiology 49:1359-1368. https://doi.org/10.1099/00207713-49-4-1359 
Niedz RP, McKendree WL, Shatters RC (2003). Electroporation of embryogenic protoplasts of sweet organe (Citrus sinensis (L.) Osbeck) and regeneration of transformed plants. In Vitro Cellular \& Developmental Biology-Plant 39:586-594. https://doi.org/10.1079/ivp2003463

Noindorf L, Bonatto AC, Monteiro RA, Souza EM, Rigo LU, Pedrosa FO, Steffens MB, Chubatsu LS (2011). Role of P II proteins in nitrogen fixation control of Herbaspirillum seropedicae strain SmR1. BMC Microbiology 11:8. https://doi.org/10.1186/1471-2180-11-8

Nowak P, Soupas L, Thomas-Oates J, Lindstrom K (2004). Acacia senegal and Prosopis chilensis-nodulating rhizobia Sinorhizobium arboris HAMBI 2361 and S. kostiense HAMBI 2362 produce tetra- and pentameric LCOs that are N-methylated, O-6-carbamoylated and partially sulfated. Carbohydrate Research 339:1061-1067. https://doi.org/10.1016/j.carres.2004.02.013

Nyoki D, Ndakidemi PA (2018). Rhizobium inoculation reduces P and K fertilization requirement in corn-soybean intercropping. Rhizosphere 5:51-56. https://doi.org/10.1016/j.rhisph.2017.12.002

Oliveira MAS, Baura VA, Aquino B, Hergo LF, Kadowaki MAS, Chubatsu LS, ... Monteiro RA (2009). Role of conserved cysteine residues in Herbaspirillum seropedicae NifA activity. Research in Microbiology 160:389-395. https://doi.org/10.1016/j.resmic.2009.06.002

Oliveira MAS, Aquino B, Bonatto AC, Huergo LF, Chubatsu LS, Pedrosa FO, ... Monteiro RA (2012). Interaction of GlnK with the GAF domain of Herbaspirillum seropedicae NifA mediates $\mathrm{NH}_{4}^{+}$-regulation. Biochimie 94:10411047. https://doi.org/10.1016/j.biochi.2012.01.007

O'Neill K, Larsen JS, Curtis WR (2008). Scale-up of Agrobacterium-mediated transient protein expression in bioreactorgrown Nicotiana glutinosa plant cell suspension culture. Biotechnology Programme 24:372-376. https://doi.org/10.1021/bp0703127

Osei O, Abaidoo RC, AhiaborBDK, Boddey RM, Rouws LFM (2018). Bacteria related to Bradyrhizobium yuanmingense from Ghana are effective groundnut micro-symbionts. Applied Soil Ecology 127:41-50. https://doi.org/10.1016/j.apsoil.2018.03.003

Ozawa K (2009). Establishment of a high efficiency Agrobacterium-mediated transformation system of rice (Oryza sativa L.). Plant Science 176:522-527. https://doi.org/10.1016/j.plantsci.2009.01.013

Ozawa K, Takaiwa F (2010). Highly efficient Agrobacterium-mediated transformation of suspension-cultured cell clusters of rice (Oryza sativa L.). Plant Science 179:333-337. https://doi.org/10.1016/j.plantsci.2010.06.011

Pacurar DI, Thordal-Christensen H, Pacurar ML, Pamfil D, Botez C, Bellini C (2011). Agrobacterium tumefaciens: From crown gall tumors to genetic transformation. Physiological and Molecular Plant Pathology 76:76-81. https://doi.org/10.1016/j.pmpp.2011.06.004

Palanichelvam K, Oger P, Clough SJ, Cha C, Bent AF, Farrand SK (2000). A second t-region of the soybeansupervirulentchrysopine-type Ti plasmid pTiChry5, and construction of a fully disarmed vir helper plasmid. MolecularPlant-Microbe Interactions 13:1081-1091. https://doi.org/10.1094/mpmi.2000.13.10.1081

Park SY, Jeong MH, Wang HY, Kim JA, Yu NH, Kim S, ... Hur JS (2013). Agrobacterium tumefaciens-mediated transformation of the lichen fungus, Umbilicaria muehlenbergii. PLoS One 8(12):e83896. https://doi.org/10.1371/journal.pone.0083896

Pedrosa FO, Benelli EM, Yates MG, Wassem R, Monteiro RA, Klassen G, ... Rigo LU (2001). Recent developments in the structural organization and regulation of nitrogen fixation genes in Herbaspirilum seropedicae. Journal of Biotechnology 91:189-195. https://doi.org/10.1016/s0168-1656(01)00343-1

Peix A, Ramirez-Bahena MH, Velazquez E, Bedmar EJ (2015). Bacterial associations with legumes. Critical Reviews in Plant Science 34:17-42. https://doi.org/10.1080/07352689.2014.897899

Perez-Peralta PJ, Ferrera-Cerrato R, Alarcon A, Trejo-Tellez LI, Cruz-Ortega R, Silva-Rojas HV (2019). Respuesta del simbiosistema frijol (Phaseolus vulgaris L.) y Rhizobium tropici CIAT899 ante elefectoalelopatico de Ipomoea purpurea L. Roth. Revista Argentina De Microbiologia 51(1):47-55. https://doi.org/10.1016/j.ram.2018.01.006

Pessoa DDV, Vidal MS, Baldani JI, Simoes-Araujo JL (2016). Validation of reference genes for RT-qPCR analysis in Herbaspirillum seropedicae. Journal of Microbiology Methods 127:193196. https://doi.org/10.1016/j.mimet.2016.06.011

Pizzimenti S, Ciamporcero E, Daga M, Pettazzoni P, Arcaro A (2013). Interaction of aldehydes derived from lipid peroxidation and membrane proteins. Frontiers in Physiology 4:1-17. https://doi.org/10.3389/fphys.2013.00242

Prell J, Poole P (2006). Metabolic changes of rhizobia in legume nodules. Trends in Microbiology 14(4):161-168. https://doi.org/10.1016/j.tim.2006.02.005 
Radwan SS, Dashti N, El-Nemer I, Khanafer M (2007). Hydrocarbon utilization by nodule bacteria and plant growthpromoting rhizobacteria. International Journal of Phytoremediation 9:475-486. https://doi.org/10.1080/15226510701709580

Ramirez-Bahena MH, Velazquez E, Fernandez-Santos F, Peix A, Martinez-Molina E, Mateos PF (2009). Phenotypic, genotypic and symbiotic diversities in strain nodulating clover in different soils in Spain. Canadian Journal of Microbiology 55:1207-1216. https://doi.org/10.1139/w09-074

Ramirez-Bahena MH, Peix A, Rivas R, Camacho R, Rodriguez-Navarro DN, Mateos PF, ... Velazquez E (2009). Bradyrhizobium pachyrhizi sp. nov. and Bradyrhizobium jicamae sp. nov., isolated from effective nodules of Pachyrhizuserosus. International Journal of Systematics and Evolutionary Microbiology 59:1929-1934. https://doi.org/10.1099/ijs.0.006320-0

Ramirez-Bahena MH, Flores-Felix JD, Velazquez E, Peix A (2010). The Mimosoid tree Leucaena leucocephala can be nodulated by the symbiovargenistearum of Bradyrhizobium canariense. Systematic and Applied Microbiology 43:126041. https://doi.org/10.1016/j.syapm.2019.126041

Reichman SM (2007). The potential use of the legume-rhizobium symbiosis for the remediation of arsenic contaminated sites. Soil Biology and Biochemistry 39:2587-2593. https://doi.org/10.1016/j.soilbio.2007.04.030

Reichman SM (2014). Probing the plant growth-promoting and heavy metal tolerance characteristics of BradyrhizobiumjaponicumCB1809. European Journal of Soil Biology 63:7-13. https://doi.org/10.1016/j.ejsobi.2014.04.001

Reinhold BB, Chan SY, Reuber TL, Marra A, Walker GC, Reinhold VN (1994). Detailed structural characterization of succinoglycan, the major exopolysaccharide of Rhizobium meliloti Rm 1021. Journal of Bacteriology 176:19972002. https://doi.org/10.1128/jb.176.7.1997-2002.1994

Rejili M, Mahdhi M, Fterich A, Dhaoui S, Guefrachi I, Abdeddayem R, Mars M (2012). Symbiotic nitrogen fixation of wild legumes in Tunisia: soil fertility dynamics, field nodulation and nodules effectiveness. Agriculture, Ecosystems and Environment 157:60-69. https://doi.org/10.1016/j.agee.2012.01.015

Riah N, Bena G, Djekoun A, Heulin K, de Lajudie P, Laguerre G (2014). Genotypic and symbiotic diversity of rhizobium populations associated with cultivated lentil and pea in sub-humid and semi-arid regions of Eastern Algeria. Systematic and Applied Microbiology 37(5):368-375. https://doi.org/10.1016/j.syapm.2013.12.008

Riaziat A, Soleymani A, Shahrajabian MH (2012). Changes in seed yield and biological yield of six wheat cultivars on the basis of different sowing dates. Journal of Food, Agriculture and Environment 10(1):467-469.

Rogel MA, Ormeno-Orrillo E, Martinez-Romero E (2011). Symbiovars in rhizobia reflect bacterial adaptation to legumes. Systematic and Applied Microbiology 34:96-104. https://doi.org/10.1016/j.syapm.2010.11.015

Rome S, Fernandez MP, Brunel B, Normand P, Cleyet-Marel JC (1996). Sinorhizobium medicae sp. non., isolated from annual Medicago spp. International Journal of Systematic Bacteriology 46:972-980. https://doi.org/10.1099/00207713-46-4-972

Roumiantseva ML, YakutkinaVV, Damman-Kalinowski T, Sharypova LA, Keller M, Simarov BV (1999). Comparative analysis of structural organization of the genome in alfalfa nodule bacteria Sinorhizobium medicae and Sinorhizobium meliloti. Russian Journal of Genetics 35:135-159.

Sadowskyt MJ, Bohloolt BBEN (1986). Growth of fast- and slow-growing rhizobia. Applied and Environmental Microbiology 52:951-953. https://doi.org/10.1128/aem.52.4.951-953.1986

Saidi S, Ramirez-Bahena MH, Santillana N, Zuniga D, Alvarez-Martinez E, Peix A, Mhamdi R, Velazquez E (2014). Rhizobium laguerreae sp. nov. nodulates Vicia faba on several continents. International Journal of Systematic and Evolutionary Microbiology 64:242-247. https://doi.org/10.1099/ijs.0.052191-0

Sanchez-Pardo B, Zornoza P (2014). Mitigation of Cu stress by legume-Rhizobium symbiosis in white lupin and soybean plants. Ecotoxicology and Environmental Safety 102:1-5. https://doi.org/10.1016/j.ecoenv.2014.01.016

Sanchez AC, Gutierrez RT, Santana RC, Urrutia AR, Fauvart M, Michiels J, Vanderleyden J (2014). Effects of coinoculation of native Rhizobium and Pseudomonas strains on growth parameters and yield of two contrasting Phaseolus vulgaris L. genotypes under Cuban soil conditions. European Journal of Soil Biology 62:105-112. https://doi.org/10.1016/j.ejsobi.2014.03.004

Sanchez-Romero JJ, Olguin LF (2015). Choline sulfatase from Ensifer (Sinorhizobium) meliloti: Characterization of the unmodified enzyme. Biochemistry and Biophysics Reports 3:161-168. https://doi.org/10.1016/j.bbrep.2015.08.002 
Saranya Devi E, Vijayendra SVN, Shamala TR (2012). Exploration of rice bran, an agro-industry residue, for the production of intra- and extra-cellular polymers by Sinorhizobium meliloti MTCC 100. Biocatalysis and Agricultural Biotechnology 1:80-84. https://doi.org/10.1016/j.bcab.2011.08.014

Satyavathi VV, Prasad V, Gita Lakshmi B, Lakshmi Sita G (2002). High efficiency transformation protocol for three Indian cotton varieties via Agrobacterium tumefaciens. Plant Science 162:215-223. https://doi.org/10.1016/s0168-9452(01)00547-7

Sawada H, Kuykendall LD, Young JM (2003). Changing concepts in the systematic of bacterial nitrogen-fixing legume symbionts. Journal of General and Applied Microbiology 49:155-179. https://doi.org/10.2323/jgam.49.155

Selvaraj A, Thangavel K, Uthandi S (2020). Arbuscular mycorrhizal fungi (Glomus intraradices) and diazotrophic bacterium (Rhizobium BMBS) primed defense in blackgram against herbivorous insect (Spodoptera litura) infestation. Microbiological Research 231:126355. https://doi.org/10.1016/j.micres.2019.126355

Serrato RV, Balsanelli E, Sassaki GL, Carlson RW, Muszynski A, Monteiro RA, ... Iacomini M (2012). Structural analysis of Herbaspirillum seropedicae lipid- A and of two mutants defective to colonize maize roots. International Journal of Biological Macromolecules 51:384-391. https://doi.org/10.1016/j.ijbiomac.2012.05.034

Servin-Garciduenas LE, Moral AZ-D, Ormeno-Orrillo E, Rogel MA, Delgado-Salinas A, Sanchez F, Martinez-Romero E (2014). Symbiont shift towards Rhizobium nodulation in a group of phylogenetically related Phaseolus species. Molecular Phylogenetics and Evolution 79:1-11. https://doi.org/10.1016/j.ympev.2014.06.006

Shah V, Subramaniam S (2018). Bradyrhizobium japonicum USDA110: A representative model organism for studying the impact of pollutants on soil microbiota. Science of the Total Environment 624:963-967. https://doi.org/10.1016/j.scitotenv.2017.12.185

Shahid M, Saghir Khan M (2019). Fungicide tolerant Bradyrhizobium japonicum mitigate toxicity and enhance green gram production under hexaconazole stress. Journal of Environmental Sciences 78:92-108. https://doi.org/10.1016/j.jes.2018.07.007

Shamseldin A, Abdelkhalek A, Sadowsky MJ (2017). Recent changes to the classification of symbiotic, nitrogen-fixing, legume-associating bacteria: a review. Symbiosis 71:91-109. https://doi.org/10.1007/s13199-016-0462-3

Sharajabian MH, Sun W, Cheng Q (2019a). Climate change, acupuncture and traditional Chinese herbal medicines. Pharmacognosy Communications 9(3):91-95. https://doi.org/10.5530/pc.2020.1.10

Shahrajabian MH, Sun W, Cheng Q (2019b). Clinical aspects and health benefits of ginger (Zingiber officinale) in both traditional Chinese medicine and modern industry. Acta Agriculturae Scandinavica, Section B - Soil and Plant Science. https://doi.org/10.1080/09064710.2019.1606930

Shahrajabian MH, Sun W, Cheng Q (2020). Chinese star anise (Illicium verum) and pyrethrum (Chrysanthemum cinerariifolium) as natural alternatives for organic farming and health care- A review. Australian Journal of Crop Science 14(03):517-523. https://doi.org/10.21475/ajcs.20.14.03.p2209

Shamala TR, Rohinishree YS, Vijayendra SVN (2014). Biosynthesis of multiple biopolymers by Sinorhizobium meliloti CFR 14 in high cell density cultures through fed batch fermentation. Biocatalysis and Agricultural Biotechnology 3:316-322. https://doi.org/10.1016/j.bcab.2014.05.004

Shamseldin A, Moawad H, El-Rahim WMA, Sadowsky MJ (2014). Near-full length sequencing of 16S rDNA and RFLP indicates that Rhizobium etli is the dominants species nodulating Egyptian winter Berseem clover (Trifolium $\begin{array}{lllll}\text { alexandrum } & \text { L.). Systematic and } & \text { and 128. }\end{array}$ https://doi.org/10.1016/j.syapm.2013.08.002

Shamseldin A, Carro L, Peix A, Velazquez E, Moawad H, Sadowsky MJ (2016). The symbiovartrifolii of Rhizobium bangladeshense and Rhizobium aegyptiacum sp. nov. nodulate Trifolium alexandrinum in Egypt. Systematic and Applied Microbiology 39:275-279. https://doi.org/10.1016/j.syapm.2016.05.002

Shao C, Yin Y, Qi Z, Li R, Song Z, Li Y, Wang Z (2015). Agrobacterium tumefaciens-mediated transformation of the entomopathogenic fungus Nomuraea rileyi Fungal Genetics and Biology 83:19-25. https://doi.org/10.1016/j.fgb.2015.08.002

Shao S, Zhang X, van Heusden GPH, Hooykaas PJJ (2018). Complete sequence of the tumor-inducing plasmid pTiChry5 from the hypervirulent Agrobacterium tumefaciens strain Chry5. Plasmid 96-97:1-6. https://doi.org/10.1016/j.plasmid.2018.02.001

Sharma M, Schmid M, Rothballer M, Hause G, Zuccaro A, Imani J, ... Kogel KH (2008). Detection and identification of bacteria intimately associated with fungi of the order Sebacinales. Cell Microbiology 10:2235-2246. https://doi.org/10.1111/j.1462-5822.2008.01202.x 
Shaw SL, Long SR (2003). Nod factor elicits two separable calcium responses in Medicago truncatula root hair cells. Plant Physiology 131:976-984. https://doi.org/10.1104/pp.005546

Shewry PR, Jones HD, Halford NG (2008). Plant biotechnology: transgenic crops. Food Biotechnology 149-186. https://doi.org/10.1007/10_2008_095

Shivani, Tiwari S (2019). Enhanced Agrobacterium-mediated transformation efficiency of banana cultivar Grand Naine by reducing oxidative stress. Scientia Horticulturae 246:675685. https://doi.org/10.1016/j.scienta.2018.11.024

Sieberer BJ, Timmers ACJ, Emons AMC (2005). Nod factors alter the microtubule cytoskeleton in Medicago truncatula root hairs to allow root hair reorientation. Molecular Plant-Microbe Interactions 18:1195-1204. https://doi.org/10.1094/mpmi-18-1195

Silva LR, Pereira MJ, Azevedo J, Mulas R, Velazquez E, Gonzalez-Andres F, Valentao P, Andrade PB (2013). Inoculation with Bradyrhizobium japonicum enhances the organic and fatty acids content of soybean (Glycine max (L.) Merrill) seeds. Food Chemistry 141:3636-3648. https://doi.org/10.1016/j.foodchem.2013.06.045

Singh H, Dixit S, Verma PC, Singh PK (2014). Evaluation of total phenolic compounds and insecticidal and antioxidant activities of tomato hairy root extract. Journal of Agriculture and Food Chemistry 62:2588-2594. https://doi.org/10.1021/jf405695y

Singh R, Dubey AK, Sanyal I (2019). Optimisation of adventitious shoot regeneration and Agrobacterium-mediated transformation in Canna $x$ genetalis (Canna Lily). Horticultural Plant Journal 5(1):39-46. https://doi.org/10.1016/j.hpj.2018.11.002

Smith EF, Townsend CO (1907). A plant-tumor of bacterial origin. Science 24:671-673. https://doi.org/10.1126/science.25.643.671

Smith LT, Smith GM (1989). An osmoregulated dipeptide in stressed Rhizobium meliloti. Journal of Bacteriology 171:4714-4717. https://doi.org/10.1128/jb.171.9.4714-4717.1989

Soleymani A, Shahrajabian MH, Naranjani L (2011a). The responses of qualitative characteristics and solar radiation absorption of berseem clover cultivars to various nitrogen fertilizers levels. Journal of Food, Agriculture and Environment 9(2):319-321.

Soleymani A, Shahrajabian MH, Naranjani L (2011b). Yield and yield components of berseem clover cultivars in low nitrogen fertilizer input farming. Journal of Food Agriculture and Environment 9(2):281-283.

Soleymani A, Shahrajabian MH, Khoshkharam M (2016). The impact of barley residue management and tillage on forage maize. Romanian Agricultural Research 33:161-167.

Soria MA, Pagliero FE, Correa OS, Kerber NL, Garcia AF (2006). Tolerance of Bradyrhizobium japonicum E109 to osmotic stress and the stability of liquid inoculants depend on growth phase. World Journal of Microbiology and Biotechnology 22(11):1235-1241.

Souza EM, Pedrosa FO, Drummond M, Rigo LU, Yates MG (1999). Control of Herbaspirillum seropedicae NifA activity by ammonium ions and oxygen. Journal of Bacteriology 181:681-684. https://doi.org/10.1128/jb.181.2.681684.1999

Spaink HP, AartsA, Stacey C, Bloemberg GV, Lugtenberg BJJ, Kennedy EP (1992). Detection and separation of Rhizobium and Bradyrhizobium Nod metabolites using thin layer chromatography. Molecular Plant-Microbe Interactions 5:72-80. https://doi.org/10.1094/mpmi-5-072

Spaink H, Kondorosi A, Hooykaas PJJ (1998). The Rhizobiaceae: molecular biology of model plant-associated bacteria. Kulwer Academia Publishers, Dordrecht, pp 566. https://doi.org/10.1007/978-94-011-5060-6

Srivastava S, Srivastava AK (2007). Hairy root culture for mass production of high-value secondary metabolites. Critical Reviews in Biotechnology 27:29-43. https://doi.org/10.1080/07388550601173918

Stefan A, Can Cauwenberghe J, Rosu CM, Stedel C, Labrou NE, Flemetakis E, Efrose RC (2018). Genetic diversity and structure of Rhizobium leguminosarum populations associated with clover plants are influenced by local environmental variables. Systematic and Applied Microbiology 41:251-259. https://doi.org/10.1016/j.syapm.2018.01.007

Stefanello AA, de Oliveira MAS, Souza EM, Pedrosa FO, Chubatsu LS, Huergo LF, Dixon R, Monteiro RA (2020). Regulation of Herbaspirillum seropedicae NifA by the Glnk PII signal transduction protein is mediated by effectors binding to allosteric sites. BBA-Protein and Proteomics 1868:140348. https://doi.org/10.1016/j.bbapap.2019.140348

Stepkowski T, Zak M, Moulin L, Kroliczak J, Golinska B, Narozna D, Safronova VI, Madrzak CJ (2011). Bradyrhizobium canariense and Bradyrhizobium japonicum are the two dominant rhizobium species in root nodules of lupin and 
serradella plants growing in Europe. Systematic and Applied Microbiology 34:368-375. https://doi.org/10.1016/j.syapm.2011.03.002

Stepkowski T, Joanna B, Granada CE, Andrews M, Passaglia LMP (2018). Phylogeny and phylogeography of rhizobial symbionts nodulating legumes of the Tribe Genisteae. Genes 14:E163. https://doi.org/10.3390/genes9030163

Studholme DJ, Dixon R (2003). Domain architectures of sigma54-dependent transcriptional activators. Journal of Bacteriology 185:1757-1767. https://doi.org/10.1128/jb.185.6.1757-1767.2003

Sugui JA, Chang YC, Kwon-Chung KJ (2005). Agrobacterium tumefaciens-mediated transformation of Aspergillus fumigates: an efficient tool for insertional mutagenesis and targeted gene disruption. Applied and Environmental Microbiology 71:1798-1802. https://doi.org/10.1128/aem.71.4.1798-1802.2005

Sun J, Xu R, Xiao S, Lu Y, Zhang Q, Xue C (2018). Agrobacterium tumefaciens-mediated transformation as an efficient tool for insertional mutagenesis of Kabatiellazeae. Journal of Microbiological Methods 149:96-100. https://doi.org/10.1016/j.mimet.2018.05.004

Sun W, Shahrajabian MH, Cheng Q (2019). The insight and survey on medicinal properties and nutritive components of shallot. Journal of Medicinal Plant Research 13(18):452-457. https://doi.org/10.5897/jmpr2019.6836

Sun W, Shahrajabian MH, Khoshkharam M, Cheng Q (2020a). Adaptation of acupuncture and traditional Chinese herbal medicines models because of climate change. Journal of Stress Physiology and Biochemistry 16(1):85-90. https://doi.org/10.5530/pc.2020.1.10

Szato WW, Zimmerman JL, Sundaresan V, Ausubel FM (1984). A Rhizobium meliloti symbiotic regulatory gene. Cell 36:1035-1043. https://doi.org/10.1016/0092-8674(84)90053-9

TahaK, Berraho EB, Attar IE, Dekkiche S, Aurag J, Bena G (2019). Rhizobium laguerreae is the main nitrogen-fixing symbiont of cultivated lentil (Lens culinaris) in Morocco. Systematic and Applied Microbiology 41:113-121. https://doi.org/10.1016/j.syapm.2017.09.008

Talhinhas P, Muthumeenakshi S, Neves-Martins J, Oliveira H, Sreenivasaprasad S (2008). Agrobacterium-mediated transformation and insertional mutagenesis in Colletotrichum acutatum for investigating varied pathogenicity lifestyle. Molecular Biotechnology 39:57-67. https://doi.org/10.1007/s12033-007-9028-1

Tamimi SA, Young JPW (2004). Rhizobium etli is the dominant common bean nodulating rhizobia in cultivated soils from different locations in Jordan. Applied Soil Ecology 26:193-200. https://doi.org/10.1016/j.apsoil.2004.01.003

Teng Y, Shen Y, Luo Y, Sun X, Sun M, Fu D, Li Z, Christie P (2011). Influence of Rhizobium meliloti on phytoremediation of polycyclic aromatic hydrocarbons by alfalfa in an aged contaminated soil. Journal of Hazardous Materials 186:1271-1276. https://doi.org/10.1016/j.jhazmat.2010.11.126

Thapa S, Adams CB, Trostle C (2018). Root nodulation in guar: Effects of soils, Rhizobium inoculants, and guar varieties in a controlled environment. Industrial Crops and Products 120:198-202. https://doi.org/10.1016/j.indcrop.2018.04.060

Thiruvengadam M, Praveen N, Kim EH, Kim SH, Chung IM (2014a). Production of anthraquinones, phenolic compounds and biological activities from hairy root cultures of Polygonum multiflorum Thunb. Protoplasma 251:555-566. https://doi.org/10.1007/s00709-013-0554-3

Thiruvengadam M, Praveen N, Maria John KM, Yang YS, Kim SH, Chung IM (2014b). Establishment of Momordica charantia hairy root cultures for the production of phenolic compounds and determination of their biological activities. Plant Cell Tissue and Organ Culture 118:545-557. https://doi.org/10.1007/s11240-014-0506-4

Thiruvengadam M, Rekha K, Chung I-M (2016). Induction of hairy roots by Agrobacterium rhizogenes-mediated transformation of spine gourd (Momordica dioica Roxb. ex. Willd) for the assessment of phenolic compounds and biological activities. Scientia Horticulturae 198:132-141. https://doi.org/10.1016/j.scienta.2015.11.035

Tian CF, Young JPW, Wang ET, Tamimi SM, Chen WX (2010). Population mixing of Rhizobium leguminosarum bv. Viciae nodulating Vicia faba: the role of recombination and lateral gene transfer. FEMS Microbiology and Ecology 73(3):563-576. https://doi.org/10.1111/j.1574-6941.2010.00909.x

Tombolini R, Nuti M (1989). Poly ( $\beta$-hydroxyalkanoate) biosynthesis accumulation by different Rhizobium species. FEMS Microbiology Letters 60:299-304. https://doi.org/10.1016/0378-1097(89)90414-X

Tong W, Li X, Huo Y, Zhang L, Cao Y, Wang E, Chen W, Tao S, Wei G (2018). Genomic insight into the taxonomy of Rhizobium genospecies that nodulate Phaseolus vulgaris. Systematic and Applied Microbiology 41:300-310. https://doi.org/10.1016/j.syapm.2018.03.001

Torabian S, Farhangi-Abriz S, Denton MD (2019). Do tillage systems influence nitrogen fixing in legumes? A review. Soil and Tillage Research 185:113-121. https://doi.org/10.1016/j.still.2018.09.006 
Tu C, Teng Y, Luo Y, Li X, Sun X, Li Z, Liu W and Christie P (2011). Potential for biodegradation of polychlorinated biphenyles (PCBs) by Sinorhizobium meliloti. Journal of Hazardous Materials 186:1438-1444. https://doi.org/10.1016/j.jhazmat.2010.12.008

Tullio LD, Gomes DF, Silva LP, Hungria M and Batista JSDS (2019). Proteomic analysis of Rhizobium freireiPRF $81^{\mathrm{T}}$ reveals the key role of central metabolic pathways in acid tolerance. Applied Soil Ecology 135:98-103. https://doi.org/10.1016/j.apsoil.2018.11.014

Twerdochlib AL, Chubatsu LS, Souza EM, Pedrosa FO, Steffens MBR, Yates MG, Rigo LU (2003). Expression, purification, and DNA-binding activity of the solubilized NtrC protein of Herbaspirillum seropedicae. Protein Expression and Purification 30:117-123. https://doi.org/10.1016/s1046-5928(03)00074-3

Uyanoz R, Karaca U (2011). Effects of different salt concentrations and Rhizobium inoculation (native and Rhizobium tropici CIAT899) on growth of dry bean (Phaseolus vulgaris L.). European Journal of Soil Biology 47:387-391. https://doi.org/10.1016/j.ejsobi.2011.07.007

Van Ham R, O’Callaghan M, Geurts R, Ridgway HJ, Ballard R, Noble A, Macara G, Wakelin SA (2016). Soil moisture deficit selects for desiccation tolerant Rhizobium leguminosarum bv. trifolii. Applied Soil Ecology 108:371-380. https://doi.org/10.1016/j.apsoil.2016.09.016

Van Larebeke N, Genetello C, Schell J, Schilperoort RA, Hermans AK, Van Montagu M, Hernalsteens JP (1975). Acquisition of tumor-inducing ability by non-oncogenic agrobacteria as a result of plasmid transfer. Nature 255:742-743. https://doi.org/10.1038/255742a0

Van Zeijl A, Op den Camp RHM, Denium EE, Charnikhova T, Franssen H, Op den Camp HJM, ... Geurts R (2015). Rhizobium lipo-chitooligosacharide signaling trigger accumulation of cytokinins in Medicago truncatula roots. Molecular Plant 8:1213-1226. https://doi.org/10.1016/j.molp.2015.03.010

Vanlauwe B, Hungria M, Kanampiu F, GillerKE (2019). The role of legumes in the sustainable intensification of African smallholder agriculture: lessons learnt and challenges for the future. Agricultural Ecosystems and Environment 284: 106583. https://doi.org/10.1016/j.agee.2019.106583

Vardi A, Bleichman S, Aviv D (1990). Genetic transformation of citrus protoplasts and regeneration of transgenic plants. Plant Science 69:199-206. https://doi.org/10.1016/0168-9452(90)90118-8

VazquezMM, Azcon R, Barea JM (2001). Compatibility of a wild type and its genetically modified Sinorhizobium strain with two mycorrhizal fungi on Medicago species as affected by drought stress. Plant Science 161:347-358. https://doi.org/10.1016/s0168-9452(01)00416-2

Velazquez E, Palomo JL, Rivas R, Guerra H, Peix A, Trujillo ME, ... Martinez-Molina E (2010). Analysis of core genes supports the reclassification of strains Agrobacterium radiobacter K84 and Agrobacterium tumefaciens AKE10 into the species Rhizobium rhizogenes. Systematic and Applied Microbiology 33:247-251. https://doi.org/10.1016/j.syapm.2010.04.004

Vu TD, Jousse C, Pawlicki-Jullian N, Schiltz S, Nguyen TKO, Tran TLM, ... Gontier E (2018). Datura innoxia plants hydroponically-inoculated with Agrobacterium rhizogenes display an enhanced growth and alkaloid metabolism. Plant Science 277:166-176. https://doi.org/10.1016/j.plantsci.2018.09.001

Wang F, Zhu Z, Li XH (1998). Transient expression of gus genes controlled by differential regulator sequences in citrus protoplasts. Fujian Journal of Agricultural Sciences 13:1-5.

Wang FQ, Wang ET, Zhang YF, Chen WX (2006). Characterization of rhizobia isolated from Albizia spp. in comparison with microsymbionts of Acacia spp. and Leucaena leucocephala grown in China. Systematic and Applied Microbiology 29:502-517. https://doi.org/10.1016/j.syapm.2005.12.010

Wang Z, Yang Y, Sun W, Xie S (2014). Biodegradation of nonylphenol by two alphaproteobacterial strains in liquid culture and sediment microcosm. International Biodeterioration and Biodegradation 92:1-5. https://doi.org/10.1016/j.ibiod.2014.04.004

Wang L, Cao Y, Wang ET, Qiao JY, Jiao S, Liu ZS, Zhao L, Wei GH (2016). Biodiversity and biogeography of rhizobia associated with common bean (Phaseolus vulgaris L.) in Shaanxi Province. Systematic and Applied Microbiology 39:211-219. https://doi.org/10.1016/j.syapm.2016.02.001

Wang L, Suganuma S, Hibino A, Mitsui R, Tani A, MatsumotoT, ... Nakagawa T (2019). Lanthanide-dependent methanol dehydrogenase from the legume symbiotic nitrogen-fixing bacterium Bradyrhizobium diazoefficiens strain USDA110. Enzyme and Microbial Technology 130:109371. https://doi.org/10.1016/j.enzmictec.2019.109371

Weir BS, Turner SJ, Silvester WB, Park DC, Young JA (2004). Unexpectedly diverse Mesorhizobium strains and Rhizobium leguminosarum nodulate native legume genera of New Zealand while introduced legume weeds are 
nodulated by Bradyrhizobium species. Applied Environment and Microbiology 70:5980-5987. https://doi.org/10.1128/aem.70.10.5980-5987.2004

Werner D (2007). Molecular biology and ecology of the Rhizobia-legume symbiosis. In: Pinton R, Varanini Z, Nannipieri $\mathrm{P}$ (Eds). The rhizosphere: biochemistry and organic substances at the soil-plant interface. Second edition CRC Pess, Boca Raton, FL, pp 237-266. https://doi.org/10.1201/9781420005585.ch9

Wibberg D, Blom J, Jaenicke S, Kollin F, Rupp O, Scharf B, ... Schluter A (2011). Complete genome sequencing of Agrobacterium sp. H13-3, the former Rhizobium lupine H13-3, reveals a tripartite genome consisting of a circular and a linear chromosome and an accessory plasmid but lacking a tumor-inducing Ti-plasmid. Journal of Biotechnology 155: 50-62. https://doi.org/10.1016/j.jbiotec.2011.01.010

Wibberg D, Blom J, Ruckert C, Winkler A, Albersmeier A, Puhler A, Schluter A, Scharf BE (2013). Draft genome sequence of Sinorhizobium meliloti RU11/001, a model organism for flagellum structure, motility and chemotaxis. Journal of Biotechnology 168:731-733. https://doi.org/10.1016/j.jbiotec.2013.10.015

Willis LB, Walker GC (1998). Identification of the Rhizobium meliloti alcohol dehydrogenase gene (adhA) and heterologous expression in Alcaligenes eutophus. Biochimica et Biophysica Acta (BBA) - Protein Structure and Molecular Enzymology 1384:197-203. https://doi.org/10.1016/s0167-4838(98)00048-X

Wixom AQ, Casavant NC, Kuhl JC, Xiao F, Dandurand L-M, Caplan AB (2018). Solanum sisymbriifolium plants become more recalcitrant to Agrobacterium transfection as they age. Physiological and Molecular Plant Pathology 102:209-218. https://doi.org/10.1016/j.pmpp.2018.03.004

Wolde-meskel E, van Heerwaarden J, Abdulkadir B, Kassa S, Aliyi I, Degefu T, Wakweya K, Kanampiu F, Giller KE (2018). Additive yield response of chickpea (Cicer arietinum L.) to rhizobium inoculation and phosphorus fertilizer across smallholder farms in Ethiopia. Agriculture, Ecosystems and Environment 261:144-152. https://doi.org/10.1016/j.agee.2018.01.035

Xiao X, Li Y, Qin J, He Y, CaiW, Chen Z, Xi L, Zhang J (2020). An optimized Agrobacterium tumefaciens-mediated transformation system for random insertional mutagenesis in Fonsecae monophora. Journal of Microbiological Methods 170:105838. https://doi.org/10.1016/j.mimet.2020.105838

Xu LM, Ge C, Cui Z, Li J, Fan H (1995). Bradyrhizobium lianoningense sp. nov., isolated from the root nodules soybeans. International Journal of System Bacteriology 45:706-711. https://doi.org/10.1099/00207713-45-4-706

Xu XX, Li JY, Shi PJ, Ji WL, Liu B, Zhang YH, Yao B, Fan YL, Zhang W (2016). The use of T-DNA insertional mutagenesis to improve cellulase production by the thermophilic fungus Humicola insolens Y1. Scientific Reports 6(1):1-9. https://doi.org/10.1038/srep31108

Xue S, Biondi EG (2019). Coordination of symbiosis and cell cycle functions in Sinorhizobium meliloti. BBA- Gene Regulatory Mechanisms 1862:691-696. https://doi.org/10.1016/j.bbagrm.2018.05.003

Yadav J, Verma JP (2014). Effect of seed inoculation with indigenous Rhizobium and plant growth promoting rhizobacteria on nutrients uptake and yields of chickpea (Cicer arietinum L.). European Journal of Soil Biology 63:70-77. https://doi.org/10.1016/j.ejsobi.2014.05.001

Yang J, Li G, Hu S, Bishopp A, Heenatigala PPM, Kumar S, Duan P, Yao L, Hou H (2018). A protocol for efficient callus induction and stable transformation of Spirodela polyrhiza (L.) Schleiden using Agrobacterium tumefaciens. Aquatic Botany 151:80-86. https://doi.org/10.1016/j.aquabot.2018.08.004

Yao J, Wub J, Gleave AP (1996). Transformation of citrus embryogenic cells using particle bombardment and production of transgenic embryos. Plant Science 113:175-183. https://doi.org/10.1016/0168-9452(95)04292-X

Yao S, Lyu S, An Y, Lu J, Gjermansen C, Schramm A (2019). Microalgae-bacteria symbiosis in microalgal growth and biofuel production: a review. Journal of Applied Microbiology 126:359-368. https://doi.org/10.1111/jam.14095

Yazdpour H, Shahri MM, Soleymani A, Shahrajabian MH (2012). Effects of harvesting time and harvesting height on grain yield and agronomical characters in rice ratoon (Oryza sativa L.). Journal of Food, Agriculture and Environment 10(1):438-440. https://doi.org/10.1016/0167-8809(94)00564-u

Young JM, Kuykendall LD, Martinez-Romero E, Kerr A, Sawada H (2001). A revision of Rhizobium Frank 1889, with an emended description of the genus, and the inclusion of all species of Agrobacterium Conn 1942 and Allorhizobium undicola de Lajudie et al. 1998 as new combinations: Rhizobium radiobacter, $R$. rhizogenes, $R$. rubi, $R$. undicola and $R$. vitis. International Journal of System Evolution and Microbiology 51:89103. https://doi.org/10.1099/00207713-51-1-89

YouseifSH, El-Megeed FHA, Ageez A, Cocking EC, Saleh SA (2014). Phylogenetic multilocus sequence analysis of native rhizobia nodulatingfaba bean (Vicia faba L.) in Egypt. Systematic and Applied Microbiology 37:560-569. https://doi.org/10.1016/j.syapm.2014.10.001 
Zawoznik MS, Tomaro ML (2005). Effect of chlorimuron-ethyl on Bradyrhizobium japonicum and its symbiosis with soybean. Pest Management Science 61(10):1003-1008. https://doi.org/10.1002/ps.1077

Zeng Z-H, Chen W-X, Hu Y-G, Sui X-H, Chen D-M (2007). Screening of highly effective Sinorhizobium meliloti strains for Vector alfalfa and testing of its competitive nodulation ability in the field. Pedosphere 17(2):219-228. https://doi.org/10.1016/s1002-0160(07)60028-9

Zhang XP, Harper R, Karsisto M, Lindstrom K (1991). Diversity of rhizobium bacteria from the root nodules of leguminous tress. International Journal of System and Bacteriology 41:104-113. https://doi.org/10.1099/00207713-41-1-104

Zhang Y, Li G, He D, Yu B, Yokoyama K, Wang L (2011). Efficient insertional mutagenesis system for the dimorphic pathogenic fungus Sporothrix schenckii using Agrobacterium tumefaciens. Journal of Microbiological Methods 84:418-422. https://doi.org/10.1016/j.mimet.2011.01.017

Zhang YJ, Zheng WT, EverallI, Young JPW, Zhang XX, Tian CF, Chen WX (2015). Rhizobium anhuiense sp. nov., isolated from effective nodules of Vicia faba and Pisum sativum grown in Southern China. International Journal of System Evolution and Microbiology 65:2960-2967. https://doi.org/10.1099/ijs.0.000365

Zhang W, Wang H-W, Wang X-X, Xie X-G, Ashaduzzaman Siddikee Md, Xu R-S, Dai C-C (2016). Enhanced nodulation of peanut when co-inoculated with fungal endophyte Phomopsis liquidambari and bradyrhizobium. Plant Physiology and Biochemistry 98:1-11. https://doi.org/10.1016/j.plaphy.2015.11.002

Zhang Y-Y, Zhang D-M, Zhong Y, Chang X-J, Hu M-L, Cheng C-Z (2017). A simple and efficient in planta transformation method for pommel (Citrus maxima) using Agrobacterium tumefaciens. https://doi.org/10.1016/j.scienta.2016.11.033

Zhao L, Chen Y, Ren S, Han Y, Cheng H (2010). Studies on the chemical structure and antitumor activity of an exopolysaccharide from Rhizobium sp. N613. Carbohydrate Research 345:637-643. https://doi.org/10.1016/j.carres.2009.11.017

Ziemienowicz A (2014). Agrobacterium-mediated plant transformation: factors, application and recent advances. Biocatalysis and Agricultural Biotechnology 3:95-102. https://doi.org/10.1016/j.bcab.2013.10.004

Ziong HY, Zhang XX, Guo HJ, Ji YY, Li Y, Wang XL, ... Tian CF (2017). The epidemicity of facultative microsymbionts in faba bean rhizosphere soils. Soil Biology and Biochemistry 115:243-252. https://doi.org/10.1016/j.soilbio.2017.08.032

Zupan J, Muth TR, Draper O, Zambryski P (2000). The transfer of DNA from Agrobacterium tumefaciens into plants: a feast of fundamental insights. The Plant Journal 23:11-28. https://doi.org/10.1046/j.1365-313x.2000.00808.x

Zurdo-PineiroJL, Garcia-Fraile P, Rivas R, Peix A, Leon-Barrios M, Willems A, ... van Berkum P (2009). Rhizobia from Lanzarote, the Canary Islands, that nodulate Phaseolus vulgaris have characteristics in common with Sinorhizobium meliloti isolates from mainland Spain. Applied and Environmental Microbiology 75: 2354-2359. https://doi.org/10.1128/aem.02811-08

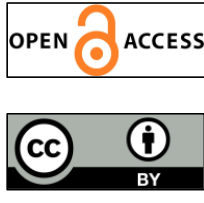

The journal offers free, immediate, and unrestricted access to peer-reviewed research and scholarly work. Users are allowed to read, download, copy, distribute, print, search, or link to the full texts of the articles, or use them for any other lawful purpose, without asking prior permission from the publisher or the author.

License -Articles published in NotulaeBotanicaeHortiAgrobotanici Cluj-Napoca are Open-Access, distributed under the terms and conditions of the Creative Commons Attribution (CC BY 4.0) License. (c) Articles by the authors; UASVM, Cluj-Napoca, Romania. The journal allows the author(s) to hold the copyright/to retain publishing rights without restriction. 